\title{
SCHOLASTYCZNE I NEOSCHOLASTYCZNE DYSKUSJE NAD NATURĄ CZASU
}

\author{
WSTEP.
}

Problem czasu stanowi ciągle dyskusyjne, otwarte, ,niepokojące” i ,wymykające się ujęciu" 1 zagadnienie w filozofii chrześcijańskiej zarówno dawnej, jak i współczesnej. Scholastycy, a za nimi neoscholastycy, przejęli wprawdzie naukę Arystotelesa i później św. Tomasza, starali się jednak oświetlić to zagadnienie $z$ różnych punktów widzenia. Zbyt uproszczonym byłby sąd, że nie wyszli poza powtarzanie i analizowanie definicji czasu podanej przez Arystotelesa. W poprzedniej pracy o czasie starałem się właśnie to wykazać, wyróżniając na podstawie analizy poglądów trzy kierunki, trzy nurty w scholastyce i neoscholastyce, ujmujące $z$ różnych stron zagadnienie natury i realności czasu ${ }^{2}$.

W niniejszym artykule próbuję z tego punktu widzenia ocenić poglądy innych, nie uwzględnionych w poprzedniej pracy autorów scholastycznych i neoscholastycznych, aby obraz ich myśli na czas był pełniejszy i dokładniejszy. Wynikła także potrzeba pewnych uzupełnień i poprawek, które dotyczą zagadnienia inicjatorów poszczególnych kierunków, oraz pełniejszej, krytycznej oceny scholastycznych teoryj czasu.

Tym, co nas najbardziej interesuje w rozważaniach o czasie, jest problem jego natury i realności. Według F. Beemelmansa tak właśnie ujmował to zagadnienie Akwinata, ponieważ jego rozwiązanie problemu czasu wskazuje na to, co jest realne $\mathrm{w}$ czasie ${ }^{3}$. Dlatego za podstawę

1 Tak określają to zagadnienie J. E. Charon, Du Temps de l'Espace et des Hommes, Paris 1962. 19 i H. D. Gardeil, Initiation à la philosophie de S. Thomas d'Aquin, II, Cosmologie, Paris 1953', 75.

2 Zob. T. Wojciechowski, Teorie czasu scholastyczne a einsteinowska, w: „Collectanea Theologica", 26 (1955) 663-776.

3 Zeit und Ewigkeit nach Thomas von Aquino, w: Beiträge zur Geschichte der Philosophie des Mittelalters, Bd 17, H. 1, Münster i. W. 1914, 12. 
podziału poglądów na czas na trzy kierunki wziąłem rolę rozumu i rzeczy w konstytuowaniu pojęcia czasu. Zgodnie z tradycją scholastyczną można wyróżnić w pojęciu czasu jego stronę formalną (formalitas), oraz jego całkowitość względnie zupełność (totalitas). Do pierwszego kierunku zaliczono tych autorów, którzy za św. Tomaszem utrzymują, że czas jest bytem rozumu z podstawą $\mathrm{w}$ rzeczy, a więc istnieje formalnie w rozumie, a całkowicie $\mathrm{i}$ w rozumie $\mathrm{i} w$ rzeczach. Do drugiego kierunku zaliczono Toletusa i jego zwolenników, według których czas istnieje wprawdzie formalnie w rzeczach, jednak dla swej zupełności domaga się ujęcia przez rozum. Istnieje przeto formalnie w rzeczach, a całkowicie w rzeczach i rozumie. Zgodnie $z$ trzecim kierunkiem czas istnieje formalnie i zupełnie $\mathrm{w}$ rzeczach ${ }^{4}$.

Spośród autorów neoscholastycznych J. Hellin SJ podał w 1955 r. podział scholastycznych poglądów na czas, podobny pod pewnym względem do mojego podziału. Biorąc za podstawę podziału również problem realności czasu, wyróżnia Hellin cztery grupy autorów. Pierwszą stanowią ci, którzy zaprzeczają w ogóle wszelkiej realności czasu fizycznego. Hellin nie podaje zwolenników tego poglądu. Drugą grupę stanowią autorzy reprezentujący pogląd, że realność czasu jest zależna od duszy liczącej. Tę zależność można rozumieć podwójnie: Zgodnie z pierwszym rozumieniem czas jest konstytuowany przez duszę liczącą i do tej podgrupy zalicza takich autorów, jak Farges, Mendive, Nys, Gatterer, Pesch ii. Zgodnie $z$ drugim rozumieniem czas istnieje wtedy, gdy istnieje liczalny ruch, chociaż by nie był zliczany przez duszę liczącą. Do tej podgrupy zalicza Arystotelesa, św. Tomasza, św. Bonawenturę, Toletusa, Suareza, Schaafa, Hoenena ii. Według trzeciej grupy autorów czas istnieje niezależnie od umysłu. Hellin znów nie podaje zwolenników tego poglądu. Czwarta grupa autorów, do której Hellin zalicza sam siebie, rozróżnia czas realny, ontologiczny, niezależny od jakiegokolwiek aktu umysłu i nie zawierający w sobie relacji do niczego oraz czas w aspekcie miary, zakładający z konieczności akt umysłu liczącego czy mierzącego ${ }^{5}$.

Wydaje się, że nie można przyjąc podziału zaproponowanego przez Hellina, a to dlatego, że podział nie został przeprowadzony konsekwentnie. Trudno bowiem zrozumieć, co stanowi o różnicy między drugą podgrupą drugiego kierunku a grupą trzecią czy czwartą. Nie można także zgodzić się na zaproponowane przez Hellina zaszeregowanie autorów scholastycznych do poszczególnych grup. Sam Hellin idzie wyraźnie za nauką Suareza, lecz zalicza go do grupy drugiej, podczas gdy siebie do grupy czwartej. Ponadto nie można zaliczać do jednej grupy św. Tomasza, Toletusa i Suareza, gdyż są to typowi przedstawiciele trzech

4 Teorie czasu scholastyczne a einsteinowska, 700-701.

5 Cosmologia. Philosophiae scholasticae Summa, t. II, Matritii 1955, 147. 
różnych poglądów na realność czasu, oraz rolę rozumu i rzeczy w konstytuowaniu pojęcia czasu. Czwarta grupa, do której Hellin zalicza siebie, jest wydzielona sztucznie, gdyż wprowadza nową podstawę podziału, którą jest rozróżnienie czasu ontologicznego i czasu jako miary. Tymczasem to rozróżnienie nie jest czymś specyficznym dla Hellina, gdyż wszyscy scholastycy rozróżniają czas jako liczbę i czas jako miarę ruchu. $\mathrm{W}$ dalszych rozważaniach uwzględnię przeto podział podany $\mathrm{w}$ mej poprzedniej pracy o czasie.

\section{KIERUNEK TOMISTYCZNY}

Duża grupa autorów, idąc za nurtem tomistycznym, ujmuje czas jako byt rozumu, istniejący formalnie $\mathrm{w}$ umyśle, $\mathrm{z}$ podstawą $\mathrm{w}$ rzeczach. Zgodnie z założeniem wyżej podanym, omówię tych autorów tej właśnie grupy, których nie uwzględniłem w poprzedniej pracy. Jan Capreolus przytacza teksty św. Tomasza i dochodzi do tych samych wniosków, ${ }^{\circ}$ co Akwinata, że czas nie jest niczym innym, jak liczbą ruchu istniejącą formalnie w umyśle. Capreolus podaje następujące uzasadnienie tego twierdzenia: podobnie jak to, co należy do racji ruchu, nie istnieje poza umysłem, tak i to, co należy do racji czasu, istnieje w duszy. Wszystko bowiem to, co stanowi rację ruchu i czasu, istnieje aktualnie tylko dzięki czynności duszy lub jakiegoś innego rozumu, który zbiera razem to, co nie istnieje $\mathrm{w}$ akcie naraz poza umysłem ${ }^{6}$.

J. van der Aa SJ stwierdza, że czas pojęty formalnie jest bytem rozumowym $z$ podstawą $w$ rzeczy, dorzuca jednak pewne nowe ujęcie. Przez czas bowiem pojęty formalnie rozumie zdolność (capacitas) lub możliwość (possibilitas) przyjmowania i zawierania równo płynącego następstwa części jednych po drugich. Zdolność ta pojęta formalnie nie posiada aktualnej bytowości, lecz jako byt jest ujmowana tylko przez rozum. Wystarczającą podstawę w rzeczach stanowi dla tej zdolności wewnętrzna możliwość następczych ruchów. Czas istnieje przeto formalnie w umyśle, jako wyabstrahowane następstwo płynących części, lecz posiada podstawę $\mathrm{w}$ rzeczach $\mathrm{w}$ realnym następstwie części ruchu ${ }^{7}$.

Maciej Schneid dzieli całość czasu na części przeszłe, teraźniejsze i przyszłe. Pyta, która z tych części jest rzeczywista i obiektywna? Jedynie realnym w czasie, odpowiada, jest niepodzielny moment ,teraz" i on stanowi obiektywną i realną podstawę czasu. Części przeszłe i przyszłe są dorzucone przez nasze myślenie i stanowią subiektywny element czasu. Dlatego ich łączność z rzeczywistym „,teraz” nie jest czymś obiek-

6 Johannis Capreoli Tholosani, Defensiones Theologiae Divi Thomae Aquinatis, t. III, Turonibus $1902,153$.

7 Praelectionum philosophiae scholasticae brevis conspectus, ed. altera, vol. II, Cosmologia et Organologia, Lovanii 1888, 129-130. 
tywnym, lecz jest wytworem naszego umysłu. W ten sposób dochodzi Schneid do stwierdzenia, że ze względu na części przeszłe i przyszłe momentem formalnym konstytuującym nasze pojęcie czasu nie jest moment obiektywny, lecz element subiektywny. Ruch, czy raczej płynące "teraz”, stanowi wprawdzie podstawę czasu, jednakże dopiero refleksyjna czynność naszego umysłu, mierząca i licząca części, stwarza $\mathrm{z}$ tego materiału pojęcie czasu.

Ze stwierdzenia, że rzeczywistą częścią czasu jest płynące „teraz”, wyprowadza Schneid wniosek, że czas posiada tylko jeden wymiar, mianowicie długość, którą należy rozumieć w sensie ontologicznym a nie przestrzennym. Czas jest dany we wszystkich rzeczach i wszędzie przebiega jednokierunkowo, w jednym wymiarze długości. Z tych wielorakich linij czasowych powstaje jednoczesność wtedy, gdy różne ruchy biegną naraz obok siebie. Ta jednoczesność nie sprawia jednak powierzchni czasowej, gdyż polega tylko na porównywaniu czasowych trwań ze sobą. Każdy czasowy ruch powstaje i przebiega samodzielnie i w każdym z nich jedynie umysł wyróżnia przeszłość, teraźniejszość i przyszłość 8 .

W podobnym kierunku zmierzają wywody A. Farges'a Sulpicjanina, choć początkowo zdaje się on skłaniać ku rozwiązaniom Suareza. Podobnie jak Suarez uważa, że czas jest trwaniem następczym, które stwierdzamy w zjawiskach naszej zmysłowej świadomości, oraz w nieustających zmianach otaczających nas rzeczy, szczególnie w ruchu słonca i planet. Opowiada się za obiektywnością czasu konkretnego i skończonego, a nie wyabstrahowanego, pojętego jako obejmia wszystkich rzeczy. Negacja czasu to negacja trwania i identyczności bytów zarówno materialnych, jak i duchowych, co w konsekwencji prowadzi do obalenia zasady tożsamości i sprzeczności, a więc do ruiny myśli ludzkiej.

Wydawałoby się, że Farges pójdzie dalej za rozwiązaniem Suareza, tymczasem tak się nie stało, gdyż uczynił nagły zwrot w kierunku myśli św. Tomasza. Założył bowiem, że czas i przestrzeń są modalnościami przedmiotów i naszego ciała. Ujmujemy je w rzeczywistości, która nas otacza i która jest obiektywną podstawą naszej idei czasu. Do pojęcia czasu stosujemy, pisze Farges, naukę szkoły o ogólnych ideach abstrakcyjnych, które istnieją wprawdzie tylko w naszym umyśle, jednak posiadają podstawę w realnych rzeczach. Czas jest przeto bytem myślowym z podstawą w rzeczach i taka jest tradycyjna teoria obiektywności czasu ${ }^{9}$.

Rozważanie części czasu: teraźniejszości, przeszłości i przyszłości prowadzi Farges'a znów do tej samej konkluzji. Czas wzięty w formalnej całości tych części jest bytem myślowym. Wprawdzie jest dobrze oparty o rzeczy, jednak nie istniałby nigdy bez umysłu zdolnego wskrzesić prze-

8 Die philosophische Lehre von Zeit und Raum, Mainz 1886, 14-32.

9 L'idée de continu dans l'espace et le temps, Paris 1892, 16-36. 
szłość, przewidzieć przyszłość i pojąc ich istotne relacje z teraźniejszością. Czas należy rozważać jako wieczny przepływ niepodzielnej teraźniejszej chwili, a nie jako serię nieciągłych chwil teraźniejszych położonych obok siebie. Przy czym chwila teraźniejsza jest również rezultatem abstrakcji umysłu ${ }^{10}$.

Również H. Haan SJ łączy pewne myśli Suareza z nauką św. Tomasza. Najpierw bowiem za Suarezem określa czas jako trwanie istnienia rzeczy. Przyjmuje definicję czasu Arystotelesa lecz zaznacza, że nie wyklucza ona słuszności innych określeń czasu. Później, przy rozważaniu realności czasu, przejmuje całkowicie argumentację św. Tomasza. Haan wymienia następujące alternatywy: czas jest albo trwaniem wiecznym, albo bytem swoistego rodzaju, w którym istnieją rzeczy, albo jakimś określeniem istniejącym formalnie w rzeczach, albo też istnieje formalnie $\mathrm{w}$ umyśle liczącym $\mathrm{z}$ podstawą $\mathrm{w}$ rzeczach, $\mathrm{w}$ ich zmiennym istnieniu. Po analizie odrzuca trzy pierwsze możliwości, a więc i pogląd Suareza, a przyjmuje ostatnią, czyli arystotelesowsko-tomaszowską doktrynę czasu ${ }^{11}$.

Kilkù starszych i nowszych neoscholastyków przejmuje prawie dosłownie naukę Akwinaty o czasie. I tak S. de Backer SJ pisze, że nie może powstać formalne pojęcie czasu, jeżeli zabraknie czynności umysłu, który zbiera i zatrzymuje równocześnie w swym rozważaniu części wcześniejsze i późniejsze ruchu. Tak więc właściwa, formalna racja czasu, którą jest liczenie, pochodzi od czynności umysłu ${ }^{12}$. K. Frank SJ posuwa się nawet do twierdzenia, że we wszystkich teoriach pojmuje się czas jako byt myślowy $z$ podstawą $w$ rzeczach i że tak jednomyślnie nauczają scholastycy za Arystotelesem ${ }^{13}$. M. Monaco SJ rozpatruje formalną i materialną stronę czasu. Czas realny rozważany formalnie, czyli jako samo liczenie, istnieje w duszy, natomiast rozważany materialnie, czyli jako rzecz liczona, istnieje w rzeczach ${ }^{14}$. H. D. Gardeil OP na pytanie, jaką realność należy przyznać pojęciu czasu, odpowiada słowami św. Tomasza, że to, co jest jakby materialne w czasie, polega na ruchu, natomiast to, co jest formalne, na czynności liczącej duszy. Gdyby nie było duszy, nie byłoby czasu ${ }^{15}$.

Spośród polskich autorów ks. St. Adamczyk przejmuje w całości arystotelesowsko-tomaszowskie rozumienie czasu. Według niego św. Albert Wielki i św. Tomasz nie tylko przyjęli definicję czasu Arystotelesa, ale ponadto tak ją wyjaśnili wszechstronnie, że przez parę wieków była

10 Tamże, 248-249, 274.

11 Philosophia naturalis in usum scholarum, Friburgi Brisgoviae 1894, 69-72.

12 Institutiones metaphysicae specialis, t. I, Paris-Lyon 1899, 231-232.

13 Philosophia naturalis, Friburgi Br. 1926, 77. $325-330$.

14 Praelectiones metaphysicae specialis, Pars I, Cosmologia, Romae ${ }^{31930,}$ 15 Dz. cyt., 76. 
powszechnie uznawana nie tylko przez scholastyków, lecz także przez niescholastyków. Dopiero Leibniz spróbował w inny sposób określić czas, jako porządek następstw w świecie zjawiskowym ${ }^{16}$.

Szerzej należy potraktować wypowiedzi niektórych współczesnych neoscholastyków ze względu na nowe myśli, które dorzucają do tradycyjnej, tomistycznej definicji czasu. J. de Tonquedec SJ wywodzi pojęcie czasu z realnego trwania ruchu. Umysł dzieli arbitralnie i w sposób sztuczny ruch, bierze jeden wycinek podziału za jednostkę miary, mierzy ile razy mieści się ona $\mathrm{w}$ całości i $\mathrm{w}$ ten sposób ocenia matematycznie różne trwania, ich równość czy różnice. Części wyróżnione przez umysł istnieją $\mathrm{w}$ ruchu tylko $\mathrm{w}$ możności, ponieważ nie posiadają własnych granic, a tylko granice narzucone przez umysł, zgodnie $z$ wolą obserwatora. Dlatego są to części liczalne a nie zliczone i ich aktualne zliczenie zależy od umysłu. Czas jest przeto liczbą następujących po sobie części ruchu, które służą do oceny trwania i matematycznego porównywania różnych ruchów.

Formułując liczbę, która jest czasem, abstrahujemy od specyficznych różnic ruchów i od rodzajów krzywizny. Tworząc tę liczbę, pozostajemy ściśle w dziedzinie arytmetycznej, gdyż mamy na uwadze tylko ilość i sprowadzamy wszystkie ruchy do jednego typu, który jest związany z rozciągłością przestrzenną. Ten sposób postępowania wykazuje duży udział konwencji, konstrukcji i sztuczności w formułowaniu pojęcia czasu i dlatego należy powiedzieć, że ostatecznie czas jest dziełem inteligencji ludzkiej. Rzeczywistość dostarcza tylko materii do liczenia, a więc potencjalnych części ruchu, którym dusza licząca daje formę liczby. Czas jest przeto bytem umysłu wypracowanym przez inteligencję ludzką w oparciu o rzeczywistość, gdyż pojęcie czasu wyraża w sposób sprecyzowany pewien aspekt tej rzeczywistości.

Czas nie składa się z indywidualnych i przyległych do siebie momentów (l'instant), ponieważ moment jest czymś niepodzielnym, natomiast ciągłość jest podzielna ze swej istoty i nie może powstać z części niepodzielnych. Wobec tego momenty, które umysł wyznacza w czasie, nie mogą posiadać realnego istnienia. Realnym możemy nazwać jedynie moment początkowy, którego nic nie poprzedza, oraz moment końcowy, po którym nic nie następuje $\mathrm{i}$ to tylko pod tym warunkiem, że te momenty pojmiemy jako granice, czyli krańce linii czasu ${ }^{17}$.

Tonquedec podkreśla, że czas jest dziełem inteligencji ludzkiej, która go odkrywa jako pewnego rodzaju aspekt rzeczywistości. Wyrażenie to przejął A. G. van Melsen, według którego większość filozofów patrzy na

16 Kosmologia, Lublin 1963, 210.

17 La philosophie de la nature, Première partie. La nature en général, fasc. III, Paris 1958, 66-73. 
czas jako na coś, co istnieje w rzeczywistości, ale nie oddzielnie od materii, lecz jako jej aspekt istotny. Czas jest więc realnym aspektem świata materialnego. Ze względu na to, że czas nie istnieje sam w sobie lecz wiąże się z ruchem, możemy powiedzieć, że czas jest aspektem liczbowym ruchu według tego, co było przed i po. Wszystkie ruchy we wszechświecie składają się na jeden i ten sam porządek ,przed” i ,po" i dlatego możemy mówić o jednym uniwersalnym czasie, o jednym uniwersalnym porządku ,przed" i ,po" 18.

Rolę refleksji duszy w konstytuowaniu pojęcia czasu wysuwa na pierwsze miejsce $\mathrm{H}$. Barreau w swej analizie arystotelesowskiej definicji czasu. Czas, jako liczba ruchu według części wcześniejszych i późniejszych, jest pewnego rodzaju abstrakcją ruchu. Bez duszy nie ma czasu, gdyż czas istnieje tylko dzięki refleksji duszy, dającej nam świadomość płynięcia wcześniejszych i późniejszych chwil w ruchu. Barreau wyklucza jako błędne utożsamianie chwili z samym bytem podległym ruchowi. Wprawdzie Arystoteles porównywał czas z ruchem, a chwilę z przedmiotem poruszającym się, jednakże ten ostatni jest rzeczą, podczas gdy chwila jest doznaniem duszy ${ }^{19}$.

U kilku współczesnych neoscholastyków, jak też i u wyżej wymienionego van Melsena, spotykamy określenie czasu jako porządku następstwa części jednych po drugich. J. Seiler rozróżnia pojęcie czasu i wyobrażenie czasu, które towarzyszy stale pierwszemu. Czas pojmujemy nie tylko jako następstwo naszych przeżyć, lecz także jako następstwo przebiegów w świecie zewnętrznym. Czas ujmujemy jako prosty linearny schemat porządkujący następstwo tych przebiegów. Według Seilera pogląd neoscholastyków na realność czasu zajmuje miejsce pośrednie między poglądem Kanta, który rozważał czas jako czystą subiektywną formę zmysłową a priori, a poglądem Newtona, który ujmował czas jako coś niezależnego od istniejących procesów i rzeczy ${ }^{20}$.

Podobną myśl, że czas należy pojmować jako porządek następstwa, wyraża B. Thum OSB. Wychodzi z analizy substancji, która posiada rozwijające się istnienie, z czym jest związana wielość stanów chwilowych, z których wsześniejsze są realnymi warunkami późniejszych. Całkowity rozwój substancji materialnej możemy pojąc jako uporządkowaną wielość stanów chwilowych tej samej substancji. Sama substancja i ujęcie chwil są zasadniczymi analitycznymi komponentami rozwoju, w którym dopełnia się stawanie i konstytuuje się czas jako porządek stanów i faz ${ }^{21}$.

18 Filozofia przyrody, Warszawa 1963, 264-266.

19 L'instant et le temps selon Aristote, w: „Revue Philosophique de Louvain”, t. 66 (1968) $220-224$.

20 Philosophie der unbelebten Natur, Olten 1948, 119-120.

21 Absoluter und relativer Seinsbegriff und die Theorie der Zeit, w: Sapientia Aquinatis, vol. I, Romae 1955, 185-187. 
Z. Zawirski zwraca uwagę na to, że określenie czasu jako porządku następujących po sobie części, znajdujemy po raz pierwszy u Leibniza, w jego polemice z Clarkiem. Leibniz nazywa czas porządkiem następstwa, a przestrzeń porządkiem współistnienia ${ }^{22}$. Na teren neoscholastyki przeniósł ujęcie czasu jako porządku następstwa J. Geyser, określając czas jako formę porządkującą, która tkwi w spostrzeganych rzeczywistościach 23 .

Niewątpliwie w oryginalny sposób ujmuje zagadnienie czasu W. Büchel SJ. Według niego prosta refleksja nad potocznym ujęciem czasu wykazuje, że czas pojmujemy jako coś płynącego lub przepływającego, oraz jako coś odróżnionego od przebiegu realnych procesów, które odbywają się ,,w” czasie. Wobec tego ogólne pojęcie czasu nie obejmuje realnie istniejących przedmiotów i zdarzeń. Dlatego czas jest bytem myślowym, co znaczy, że treść pojęcia czasu nie może być urzeczywistniona w sposćb odpowiadający jej dokładnie. Jako przykład takiego rodzaju pojęć podaje Büchel pojęcie „dziury”, którego treść nie znajduje urzeczywistnienia w postaci przedmiotu czy zdarzenia.

Podobnie jak Seiler, rozróżnia Büchel czas wyobrażeniowy (Zeitvorstellung) i czas umysłowy (Anschauungszeit), inaczej czas potoczny i czas myślowy. Czas ujęty myślowo określa jako ,całość położeń w porządku jednych po drugich, mogących przysługiwać przebiegowi procesów, o ile tę całość ujmujemy jako coś jednego" ${ }^{24}$. Definicję tẹ rozumie Büchel w ten sposób, że czas pojmujemy jako coś różnego i odłączonego od rzeczy i zdarzeń, oraz że zjawisko następstwa części jednych po drugich jest nam dane jako prapojęcie, na które można jedynie wskazać w doświadczeniu, lecz którego nie można zdefiniować.

Przechodząc do rozważań nad realnością czasu, przyznaje Büchel częściową rację Kantowi w tym, że powstanie wyobrażenia czasu posiada swoją podstawę w spontaniczności naszej zmysłowości, mianowicie w zmyśle wspólnym (sen.sus communis). W naszej bowiem zmysłowej zdolności poznawczej tkwi dążność do łączenia danych zmysłów zewnętrznych w wyższą jedność i całość. Stąd ujmując części następujące jedne po drugich, rzutujemy je na tło ogólne, dajemy im wspólny „horyzont”, który stanowi właśnie wyobrażenie czasu. Natomiast opracowując myślowo czas wyobrażeniowy dochodzimy do pojęciowego ujęcia czasu ( $A n-$ schauungszeit), który stoi w pewnej relacji do rzeczywistości. Ten czas opracowany myślowo, zwany czasem realnym (Realzeit), określa Büchel jako całość położeń uporządkowanych jedne po drugich, które przysłu-

22 L'évolution de la notion du temps, Cracovie 1936, 64-65; zob. także Adamczyk, dz. cyt., 210.

23 Allgemeine Philosophie des Seins und der Natur, Münster i. W. 1915, 300 nn.

24 Philosophische Probleme der modernen Physik, Pullach 1957, S. VI/2. 
gują rzeczywiście trwającym rzeczom, o ile tę całość ujmujemy jako istniejącą w sobie 25 .

W rozważaniach Büchela pozostało niejasnym zagadnienie, jaka podstawa w rzeczy odpowiada czasowi pojętemu jako byt myślowy. Czy jest nią samo uporządkowanie (element myślowy) następstwa, czy realne następstwo położeń (element rzeczowy). Podana przez niego koncepcja czasu mieści się jednak w nurcie tomistycznym, choć pewne wyrażenia przypominają raczej terminologię kantowską. Na pierwsze bowiem miejsce wysuwa się w jego koncepcji idea czasu jako porządku, oraz czynność umysłu porządkującego i ujmującego w jedność całość następstwa części jednych po drugich. A taka jest właśnie charakterystyczna cecha koncepcji arystotelesowsko-tomaszowskiej. Od koncepcji Kanta różni Büchela czas ujęty umysłowo, który bierze pod uwagę rzeczywistą relacjẹ umysłu i rzeczy.

Niektórzy neoscholastycy zwracają uwagę na stosunek czasu do wieczności. Tego rodzaju ujęcie rozróżnia w czasie aspekt horyzontalny, dotyczący rozłożenia chwil następujących po sobie, czyli stosunek chwil do siebie, oraz aspekt wertykalny, który dotyczy stosunku czasu do wieczności. J. Peters CSsR nazywa za św. Tomaszem czasowość szczegółowym sposobem, według którego byty skończone naśladują wieczność w swej działalności ${ }^{26}$.

J. Mouroux pisze, że wieczność zakłada czas, który zaczyna się i trwa wraz z jego wertykalnym stosunkiem, który go wiąże z jego transcendentalnym źródłem, czyli z wiecznością. Bez tego stosunku czas nie istnieje. Podobnie jak byt nie może istnieć bez aktu stwórczego, tak czas nie może istnieć bez wieczności, która go realizuje i rozwija. Mouroux nazywa najgłębszym paradoksem czasu właśnie to, że jest bytem permanentnie zależnym w swym rozwoju następstwa części od wieczności 27. Czas współistnieje w każdym momencie $z$ niezmienną wiecznością ${ }^{28}$.

Podobną myśl rozwija Wilfried Joest, lecz zwraca uwagę przede wszystkim na chronologiczno-horyzontalny charakter czasu. Czas wzięty w jego chronologiczno-horyzontalnym przebiegu jest wyrazem i forma tego, że byty stworzone są jakby procesem, są w drodze rozwoju, którego kresem jest uzyskanie pełnej doskonałości. Niezależnie od tego, czym czas jest w sobie, dla naszego doświadczenia zarówno nas samych jak i świata, czas jest kategorią, w której doświadczamy własny byt oraz

25 Tamże, VI/2-4.

26 De tempore et aeternitate ad mentem Sancti Thomae, w: Sapientia Aquinatis, vol. II, Romae 1956, 123.

27 Le mystère du Temps, Approche Théologique, Paris 1962, 44: „C'est peut-être le paradoxe le plus profond (sinon le plus visible) du temps, que d'être, dans sa succession même une implication permanente de l'éternité".

28 Tamże, $43-45$. 
byt świata jako proces, jako drogę, a nie jako stałość ${ }^{29}$. Jest to dynamiczne ujęcie świata, w którym czas jest wyrazem rozwoju.

\section{KIERUNEK TOLETUSOWY.}

W drugim nurcie scholastycznym $\mathrm{w}$ rozważaniach o czasie nastąpiło przesunięcie akcentu z roli umysłu na realne następstwo części w ruchu. Toletus wziął pod uwagę ten właśnie aspekt czasu i stwierdził, że czas istniałby nawet wtedy, gdyby nie było umysłu liczącego. Jednakże dla swej pełności domaga się ujęcia przez duszę. Według wyrażenia Jana od św. Tomasza czas składa się z części wcześniejszych i późniejszych, istniejących realnie poza rozumem, który zbiera je tylko w całość i daje im jednoczesne istnienie. Czas istnieje formalnie $w$ rzeczach, choć dla jego zupełności potrzebne jest ujęcie go przez rozum ${ }^{30}$.

$\mathrm{Z}$ hiszpańskich scholastyków podobne rozwiązanie zagadnienia czasu podaje Grzegorz z Walencji. Rozważając różnicę między wiecznością i czasem dochodzi do wniosku, że wieczność jest trwaniem całym naraz, gdy czas jest trwaniem zmiennym i następczym, gdyż takie jest właśnie istnienie rzeczy czasowych. Ta różnica nie przeszkadza, żebyśmy myślowo nie mogli wytworzyć pojęcia prius et posterius $\mathrm{w}$ wieczności, podobnie jak to czynimy w trwaniu czasowym. Grzegorz z Walencji nie utożsamia czasu zupełnie z trwaniem, gdyż pisze, że ruch rzeczy czasowej nie posiada w sobie czasu w sposób zupełny i właściwy. Czas pojęty właściwie i zupełnie to czas pojęty jako miara zewnętrzna trwania ${ }^{31}$.

Według W. Remera SJ prius et posterius w ruchu poznajemy w dwojaki sposób. Najpierw pod formą absolutnie ciągłą, a więc poznając „wcześniej” i ,później” poznajemy równocześnie ruch. Po wtóre poznajemy owe prius et posterius oddzielnie, gdy dusza rozróżnia je jako nie utożsamiające się ze sobą. Czas nie jest ruchem, ani częściami wcześniejszymi i późniejszymi ruchu wziętymi absolutnie, lecz jest owymi częściami w sensie liczalnym i właśnie to wyraża arystotelesowska definicja czasu. Chociaż liczba części jest ilością nieciągłą, to jednak czas jest ciągły ze względu na rzecz liczoną.

Dla złudnych i sofistycznych racyj, pisze Remer, zaprzeczano realne$\mathrm{mu}$ istnieniu czasu. Jeżeli istnieje ruch bez duszy, to istnieje również czas, ponieważ prius et posterius ruchu istnieją niezależnie od duszy. W ogóle istnienie rzeczy liczonych nie zależy od umysłu, chyba że jest to umysł Boży, który jest ich przyczyną. Podobnie jak mogą istnieć rze-

29 Die Kirche und die Parusie Jesu Christi, w: Gott in Welt. Festgabe für Karl Rahner, Bd I, Freiburg/Basel/Wien 1964, 542.

30 Scholastyczne teorie czasu a einsteinowska, 685-687; 700-701.

31 Gregorii de Valentia Metimnensis e S. J., Commentariorum Theologicorum tomi quatuor, Venetiis 1608, 162-172. 
czy zmysłowe, choćby nie istniały zmysły, tak mogą istnieć rzeczy liczalne, choćby nie było umysłu liczącego. Tekst św. Tomasza z Komentarza do Sentencyj o formalnym uzupełnianiu czasu przez duszę liczącą Remer tłumaczy w ten sposób, że chodzi w nim nie o aktualne liczenie, lecz o liczalność, której bez umysłu nie możemy pojąć ${ }^{32}$.

Ze Remerem idzie P. Geny SJ. Według niego scholastycy uczą ogólnie, że czas jest bytem realnym niezależnym od duszy. Dyskusja dotyczy jedynie problemu, czy bez duszy czas jest zupełny, czy też otrzymuje od umysłu swe uzupełnienie. Równocześnie za św. Tomaszem powtarza Geny, że czas bez duszy jest utcumque ens. W każdym momencie wziętym osobno istnieje tylko „teraz” czasu, które nie jest całym czasem. Jeżeli bierzemy pod uwagę cały czas, czyli wszystkie części naraz, to wtedy czas otrzymuje swoją zupełność przez działanie duszy ${ }^{33}$.

W duchu Toletusa rozwiązuje problem realności czasu także M. de Munnynck OP pisząc, że czas zupełny istnieje właściwie w aktualności idealnej, którą może dać umysł. Jednakże z całą pewnością czas nie jest bytem myślowym, lecz jest aktualnością samych rzeczy czasowych. Równocześnie jednak czas jest syntezą dokonaną przez umysł, który obejmuje naraz konieczną rzeczywistość przeszłości, aktualność egzystencjalną teraźniejszości i problematyczną aktualizację przyszłości ${ }^{34}$.

Rozwiązanie Toletusa nie znalazło większej ilości zwolenników wśród neoscholastyków. Ze współczesnych podobne rozwiązanie podają F. Selvaggi SJ i G. Fuente OP. Dla pierwszego z tych autorów czas jest pojęciem pochodnym i zależnym od ruchu. $Z$ jednej strony realność czasu nie jest samoistna i niezależna, natomiast $z$ drugiej nie jest prostym ujęciem czy funkcją naszego umysłu. Czas jest rzeczywistością złączoną z ruchem, o ile ta rzeczywistość może przyjąć zliczenie przez umysł. Jest to czas wewnętrzny scholastyków, a w terminologii współczesnej czas wewnętrzny rzeczy ${ }^{35}$. Fuente podkreśla, że czas biegnie niezależnie od subiektywnego rozważania przez umysł ${ }^{36}$.

\section{KIERUNEK ALBERTYŃSKO-SUAREZJAŃSKI.}

Według trzeciego nurtu scholastycznego czas istnieje formalnie i zupełnie w rzeczach. Kierunek ten posiada długą, bogatą i sięgającą daleko wstecz tradycję, gdyż znajdujemy ją już u św. Alberta Wielkiego, a nie

32 Summa praelectionum philosophiae scholasticae, ed. tertia, vol. alt., Prati $1912,121-125$.

${ }_{33}$ V. Remer, Summa philosophiae scholasticae, t. IV, Cosmologia, ed. sexta emendata et aucta a Paulo Geny SJ, Romae 1927, 230-231.

${ }_{34} \mathrm{La}$ notion du temps, w: Philosophia perennis. Festgabe Joseph Geyser zum 60 Geburtstag, Bd II, Regensburg 1930, 861.

35 Assoluto e relativo nel tempo, w: „Gregorianum”, 28 (1947) 340.

36 De natura temporis. Extractus ex Periodico Estudos Filosoficos, vol. III (1954) et vol. IV (1955) 39. 
u Suareza, jak podałem poprzednio ${ }^{37}$. Jak wszyscy scholastycy, św. Albert wychodzi z definicji czasu podanej przez Arystotelesa, która może być rozumiana podwójnie, raz jako liczba ruchu, drugi raz jako miara ruchu. Na pytanie, czy czas istnieje w umyśle czy poza umysłem, odpowiada św. Albert zgodnie z pierwszą definicją, że czas istnieje poza duszą, gdyż jest czymś z ruchu, czymś łączącym się z ruchem.

Następnie rozważa św. Albert, w jaki sposób chwila teraźniejsza stanowi substancję czasu. Samą substancję można rozumieć podwójnie. Najpierw jako to, przez co coś istnieje i w ten sposób chwila teraźniejsza nie stanowi substancji czasu, ponieważ niepodzielne nie może być substancją podzielnego. Po wtóre nazywamy substancją to, czym rzecz jest i w ten sposób niepodzielne może być substancją podzielnego ${ }^{38}$.

Drugim autorem, który w średniowieczu rozwija w oryginalny sposób naukę Arystotelesa o czasie, jest Roger Bacon OFM. Na początku swych rozważań stawia sobie zasadnicze pytanie, czy czas istnieje $\mathrm{w}$ duszy czy poza nią. Za podstawę odpowiedzi na to pytanie bierze ogólne założenie, że to, co jest ilościowe, nie może istnieć w nieilościowym. Skoro zatem czas jest czymś ilościowym i podzielnym, a dusza jest czymś nieilościowym i niepodzielnym, to czas nie może istnieć $\mathrm{w}$ duszy. Czas jest liczbą ruchu ciał, przeto istnieje w poruszającym się i w ruchu jako w podmiocie, a nie w duszy, która ze swej natury jest nieruchoma.

$\mathrm{Na}$ zarzut, że liczba istnieje w duszy, przeto i czas istnieje w umyśle, odpowiada rozróżnieniem: Liczbę należy rozumieć podwójnie, raz jako czynność liczącego, drugi raz jako formę, która odróżnia rzecz od liczącego. Liczba rozważana w pierwszy sposób istnieje w duszy, natomiast rozważana w drugi sposób istnieje w rzeczach. Czas jest liczbą rozumianą w drugi sposób i dlatego czas nie istnieje w duszy, lecz poza nią, w rzeczach. Rozważając dalej relację czasu do duszy, Bacon rozróżnia duszę jako akt ciała, oraz - zgodnie z ówczesnymi fizykalnymi poglądami - jako motor poruszający ciała niebieskie. Jeżeli mówimy o duszy $\mathrm{w}$ pierwszym znaczeniu, to czas istnieje bez odniesienia do niej. Jeżeli mówimy o duszy w drugi sposób, to czas także może istnieć bez niej, ponieważ motor ciał niebieskich nie posiada wszystkich cech duszy ${ }^{39}$.

Precyzując w dalszym ciągu swe rozważania, poddaje Bacon analizie chwilę teraźniejszą czasu. I znów rozważa ją podwójnie, trochę podobnie i trochę inaczej niż św. Albert, jako kres czasu (terminus temporis), oraz jako substancję czasu. Tak jak linia nie składa się z punktów, tak czas

37 Teorie czasu scholastyczne a einsteinowska, 690.

38 Divi Alberti Magni Physicorum lib. IV, trac. 3, c. 3 i 4; Philosophiae naturalis Isagoge, Cracoviae 1548, trac. I, a. 4, p. 2.

39 Rogeri Baconi, Opera hactenus inedita, Fasc. XIII, Quaestiones supra libros octo Phys., Londonii 1935, 247-250. 
nie jest zbiorem chwil teraźniejszych, lecz jest substancją tej chwili, rozłożoną pod różnymi istnieniami następczymi. Czas jest przeto jedną i tą samą chwilą wziętą według swej substancji, a zróżnicowaną według sukcesywnego istnienia. Jest więc jednym i tym samym momentem płynącym od swego początku do końca ${ }^{40}$.

Roger Bacon dorzuca niewątpliwie ciekawe i oryginalne myśli do arystotelesowskiej definicji czasu. Bierze pod uwagę nie tylko ówczesne fizykalne poglądy, lecz także zajmuje się stosunkiem ilościowego i podzielnego do nieilościowego i niepodzielnego. Nie wszystkie jego myśli są jasne, jednakże przeanalizowane do końca wskazują na odrębną substancję, a więc i bytowość czasu, rozkładającą się w sukcesywnym istnieniu od momentu początkowego zaistnienia czasu do momentu końcowego.

W poprzedniej pracy o czasie ${ }^{41}$ przy omawianiu poglądów Dunsa Scota podałem, że w jego dziele De rerum principio znajdujemy dwie teorie czasu. Pierwsza jest zgodna z tradycją Arystotelesa i św. Tomasza, że czas według swego istnienia materialnego jest $\mathrm{w}$ rzeczach poza umysłem, natomiast według swej racji formalnej jest w duszy i zależy od duszy. Istotnym bowiem dla pojęcia czasu jest ujęcie części wcześniejszych i późniejszych ruchu, których racja nie pochodzi od rzeczy lecz od czynności umysłu, dzięki której czas istnieje formalnie w duszy. Podobnie jak św. Tomasz, widzi wzór takiego pojmowania czasu w naturze uniwersaliów ${ }^{42}$.

W tym samym jednakowoż dziele spotykamy drugą teorię czasu, zgodną z koncepcją św. Alberta i Rogera Bacona. Podkreślając ścisły związek czasu z ruchem, dochodzi autor do pojęcia czasu jako trwania, gdyż czas to nic innego jak trwanie ruchu, które mierzy jego istotę. Skoro zaś trwanie ruchu jest czasem, a każdy ruch posiada swoje własne trwanie, to i czasy różnią się między sobą realnie. Ta różnorodność czasów płynie z rzeczy, natomiast jedność czasu jest dziełem umysłu. Jedność ta jest jednością miary, która jest wzięta z ruchu niebios ${ }^{43}$.

Wyjaśnienie tej dwutorowości poglądów podaje E. Gilson ${ }^{44}$, według którego dzieło De rerum principio powstało w ten sposób, że ktoś zebrał w jedno prace uczniów Dunsa Scota. W większości kompilacja ta jest może dziełem kard. Witalisa de Furno (†1327). Jest przeto wysoce praw-

40 Tamże, 264: „Et dico quod unum instans secundum substantiam, diversificatum secundum esse, facit tempus, nec est duo nec tria, sed unum et idem fluens a principio usque in finem".

41 Teorie czasu scholastyczne a einsteinowska, 677-678.

42 De rerum principio, Lugduni 1639 , q. 18, a. 2 i 3 .

43 Tamże, q. 20, Scholion, et a. 2.

44 Jean Duns Scot, Paris 1952, 673. 
dopodobnym, że albo obie te teorie pochodzą od różnych uczniów Dunsa Scota, albo kwestie 18 i 20 zostały zredagowane przez różnych autorów ${ }^{45}$.

Emmanuel de Goës SJ, jeden z twórców jezuickiego Komentarza do Arystotelesa zwanego Cursus Conimbricensium, rozwija swe poglądy na czas podobnie jak Roger Bacon i później Suarez. Przede wszystkim odrzuca koncepcję Arystotelesa, że czas jest bytem myślowym z podstawą w rzeczy. Sądzi bowiem, że w takim ujęciu czas nie jest bytem realnym, ani nie zawiera się w kategorii ilości, lecz jest bytem umysłu, ponieważ podział na części i ich ograniczenie dokonuje się przez czynność umysłu. Czas rozważany absolutnie jest bytem realnym, gdyż, abstrahując od jakiegokolwiek ujęcia umysłowego, ruch posiada swoje własne istnienie, a więc i swoje realne trwanie, które nie jest niczym innym jak czasem.

Czas nie różni się od ruchu rzeczowo, natomiast różni się z natury rzeczy. Pomimo jednak tego, że czas zakłada ruch, nie można czasu nazwać pochodnym ruchu, względnie według wyrażenia de Goësa „,potomkiem ruchu”, ponieważ nie można powiedzieć wprost, że czas rodzi się czy wyprowadza z ruchu. De Goës sądzi też, że artykuły paryskie słusznie odrzuciły twierdzenie, że czas istnieje tylko w umyśle, skoro czas wzięty wprost $\mathrm{w}$ sobie jest samym trwaniem ruchu ${ }^{46}$. Pogląd, że czas jest trwaniem ruchu, uważa za wspólną naukę całej szkoły perypatetyckiej ${ }^{47}$. Oczywiście tego twierdzenia de Goësa nie da się utrzymać w całej rozciągłości, gdyż nie jest to wcale wspólna nauka wszystkich perypatetyków.

Koncepcja czasu jako trwania ruchu, reprezentowana i rozpowszechniona głównie przez Suareza, znalazła wielu zwolenników wśród neoscholastyków starszych i młodszych ${ }^{48}$. Według Dominika Palmieri SJ czas jest trwaniem tej rzeczy, w której zachodzi następstwo, a takim bytem jest jedynie ruch. I to jest czas obiektywny, będący liczbą zliczoną oraz samym ciągłym następstwem zmian, w których rozróżniamy części wcześniejsze i późniejsze, podobnie jak to ma miejsce w przestrzeni. Czas subiektywny, pojęty jako liczba licząca zmiany następcze w ciągłym trwaniu ruchu, istnieje w umyśle. Jeżeli czas jest samym trwaniem ruchu, to każdy ruch posiada swój własny czas wewnętrzny. Natomiast czas zewnętrzny jest tylko miarą innych czasów i ruchów ${ }^{49}$. Podobnie rozwiązują zagadnienie

45 Por. P. Glorieux, Pour en finir avec le De rerum principio, w: „Arch. Franc. Hist"., 26 (1938) 225-234.

46 Commentarii Collegii Conimbricensis Societatis Jesu. In libros de Generatione et Corruptione Arist., Moguntiae 1606, 131-136.

47 Tamże, 138: „Non inquam satisfecit, quia negat tempus esse durationem motus, quod omnis Peripatetica schola confitetur".

$48 \mathrm{Za}$ podstawę podziału neoscholastyki na starszą i młodszą przyjmuję umownie czas powstania współczesnej fizyki atomowej. Zob. moją pracę Teoria hylemorfizmu w ujęciu autorów neoscholastycznych, Warszawa ATK 1967, 7.

49 Institutiones philosophicae, vol. II, Romae 1875, 94-97. 
czasu I. M. Cornoldi SJ 50, K. Gutberlet ${ }^{51}$, G. Lahouse SJ 52 oraz J. J. Urraburu SJ 53 .

Również A. Steuer rozróżnia czas zewnętrzny i wewnętrzny. Czas zewnętrzny istnieje niezależnie od stałego następstwa naszych myśli. Jest to czas obiektywny, astronomiczny, istniejący w postaci całego szeregu równych i przebiegających z jednakową szybkością ruchów. Natomiast w czasie wewnętrznym, subiektywnym, psychologicznym, brak jest tej stałej szybkości. Równocześnie czas, podobnie jak przestrzeń, nie jest czymś odrębnie istniejącym w rzeczach, choć istnieje poza umysłem. Dlatego czas i przestrzeń są czymś transsubiektywnym ${ }^{54}$.

M. Baưmgartner dorzuca kilka ciekawych myśli do tego zagadnienia. Według niego czynnik czasowy wpływa realnie na procesy zachodzące w naturze i dlatego posiada równie obiektywne znaczenie jak masa, szybkość i przyśpieszenie. Z tego wyprowadza Baumgartner wniosek, że zarówno rzeczy jak i zdarzenia posiadają przymiot czasowości $\mathbf{5 5}$.

Według J. Geysera czas posiada tylko jedną jedyną własność, którą jest stale płynące trwanie. Możemy przeto o czasie powiedzieć nie tyle, że jest, ile raczej że się staje przechodząc trzy stopnie: teraźniejszość, przeszłość i przyszłość. Każdy nawet najmniejszy odcinek czasowy posiada trwanie i dlatego chwila czy moment nie są częścią lecz granicą czasu, która jest poznawalna wyłącznie przez umysł. Geyser podkreśla, że jest jeden, rzeczywisty i transcendentny czas, spostrzegany przez wszystkie indywidua. Czas nie jest więc czystym obrazem świadomości. Indywidualne i podmiotowe są jedynie przeżycia i oceny czasu zachodzące w świadomości. Nie można powiedzieć, że nasza świadomość tworzy czas, ponieważ posiadamy takie procesy świadomości, w których nie przeżywamy czasu i które wobec tego byłyby bezczasowe, co jest niemożliwe do przyjęcia. Dlatego czas należy określić jako pewną formę porządkującą (Ordnungsform), która tkwi w spostrzeganych rzeczywistościach. Czas posiada istnienie realne $\mathrm{w}$ stopniu i na sposób rzeczywistości, jaka jest właściwa procesom świadomości.

Doszedłszy do stwierdzenia, że czas posiada realne istnienie w danych świadomości, rozważa Geyser zagadnienie, czy czas możemy przypisać samym transcendentnym przyczynom naszych spostrzeżeń. Czasowe istnienie bytów ma swą podstawę wyłącznie w zmienności rzeczy, a ruch jest tylko szczególnym rodzajem tej zmienności. Ponieważ zależność ta nie

50 Institutiones philosophiae speculativae, Bononiae 1878, 240-242.

51 Lehrbuch der Philosophie. Naturphilosophie, Münster 1885, 199-202.

52 Praelectiones metaphysicae specialis, vol. I, Cosmologia, Lovaniae (Lutetiae Parisiorum) Friburgi Br. 1887, 265.

53 Institutiones philosophicae, vol. II, Vallisoleti 1891, 1058.

54 Lehrbuch der Philosophie, Bd II, Hbd I, Paderborn 1909, $70 \mathrm{nn}$.

55 Grundriss der Metaphysik. Als Manuscript, Dillingen 1911, 56. 
posiada wystarczającego oparcia $\mathrm{w}$ spostrzegającym umyśle, przeto czas należy umieścić całkowicie $\mathrm{w}$ transcendentnych przyczynach naszych spostrzeżeń ${ }^{56}$. Jak widać, Geyser dochodzi do stwierdzenia realności czasu przez psychologiczno-teoriopoznawczą analizę naszej świadomości, co skłania do wniosku, że jest to polemika z teorią czasu Kanta.

J. M. Dario SJ sądzi, że nawet nie można brać pod uwagę możliwości, iż czas istnieje formalnie w umyśle, a tylko potencjalnie w rzeczach. Czas jest bowiem obiektywnym następczym trwaniem, które obejmuje istnienie zarówno nasze jak i rzeczy, gdyż czas współistnieje ze wszystkimi rzeczami i obejmuje wszystkie poszczególne zdarzenia. Do takiego ujęcia czasu dochodzi Dario przez eliminację innych możliwych ujęć czasu. Czas jest bowiem albo wiecznością Boga, albo bytem absolutnym, albo trwaniem świata. Pierwsze dwie możliwości należy z góry odrzucić, pozostaje przeto trzecia, że czas jest samym trwaniem świata. Wystarczy uznać realność zewnętrznego świata, w którym czas jest poznawalny, aby uznać, że czas jest czymś obiektywnym ${ }^{\mathbf{5 7}}$.

J. Hellin SJ rozwija suarezjańską koncepcję czasu, choć sam sądzi inaczej, jak to wyżej podano. Rozróżnia czas fizyczny i czas absolutny. Czas fizyczny, który jest trwaniem następczym, istnieje w rzeczach niezależnie od jakiegokolwiek aktu naszego umysłu. Czas fizyczny można rozważać podwójnie, czysto ontologicznie lub w aspekcie miary. Czas rozważany ontologicznie jest właśnie samym następczym trwaniem. Trwanie stanowi dla definicji czasu jakby rodzaj czy rację ogólną, natomiast następczość tego trwania jakby różnicę istotną, która stanowi czas.

Czas realny fizyczny, rozważany $w$ aspekcie miary, jest trwaniem następczym z dołączonym aktem umysłu, który porównuje trwanie z jednostką czasu i liczy, ile tych jednostek, np. godzin, owo trwanie zawiera w sobie. Zdaniem Hellina arystotelesowska definicja czasu jako liczby ruchu według części wcześniejszych i późniejszych dotyczy tego właśnie czasu. Wobec tego należy przyjąć dwie definicje, z których jedna określa czas ontologiczny jako trwanie następcze i ciągłe, druga zaś dotyczy czasu jako miary liczącej części wcześniejsze i późniejsze.

$\mathrm{Za}$ Suarezem dzieli Hellin trwanie na niestworzone i stworzone. Pierwsze jest trwaniem Bożym czyli wiecznością, drugie może być trwaniem stałym lub rozłożonym następczo. Trwanie stałe może być dowiecznością (aevum), albo momentem czasu nieciągłego. Dowieczność jest trwaniem bytów niezniszczalnych, jak np. aniołów i materii pierwszej. Chwila czasu nieciągłego jest również trwaniem stałym rzeczy niezniszczalnych, np. wewnętrznego aktu duchowego bytu (instans angelicum), lub trwaniem jakiejkolwiek substancji materialnej, która nie podlega zni-

56 Dz. cyt., 295-304.

57 Praelectiones cosmologiae, Parisiis 1923, $190 \mathrm{nn}$. 
szczeniu. Substancje cielesne są wprawdzie poddane czasowi, lecz ich trwanie nie jest czasem, ponieważ nie posiadają istnienia następczego. Trwanie następcze zachodzi wtedy, gdy części trwania nie są dane naraz lecz jedne po drugich i tego rodzaju trwanie nazywamy czasem. Jest to czas fizyczny, ponieważ jest realną, fizyczną cechą rzeczy materialnych.

Każdy ruch następczy posiada swój własny czas wewnętrzny, który może być jednoczesny lub niejednoczesny względem innych czasów wewnętrznych rzeczy (np. czas Cycerona i czas Nerona). Czasem zewnętrznym jest czas wewnętrzny jakiegoś ciała wzięty jako miara innych czasów. Natomiast czas duchowy jest trwaniem następczym ruchu lokalnego czystych duchów. Według Hellina bowiem dusza i aniołowie mogą podlegać zmianie lokalnej $i$ to ruchem przyjętym wewnątrz substancji duchowej. Niestety, nie tłumaczy szczegółowiej, w jaki sposób się to dzieje i jaka jest różnica między ruchem lokalnym duchów i rzeczy.

Definicja czasu jako bytu myślowego z podstawą w rzeczy odnosi się według Hellina do czasu absolutnego. Przez abstrakcję odrywamy trwanie następcze od rzeczy zmiennych i tak powstaje czas absolutny, który jest jeden, ciągly, jednostajny, konieczny, niezniszczalny, bez początku i końca, obejmujący wszelkie trwanie. Nazywamy ten czas absolutnym, ponieważ jest koniecznym i nieuwarunkowanym. Nazywamy go czasem czystym (tempus purum), ponieważ jest czystym trwaniem oderwanym od rzeczy zmiennych. Nazywamy go także czasem matematycznym, ponieważ stosują go matematycy w dziedzinie mechaniki i astronomii 58 .

Nowe i ciekawe myśli dorzuca do zagadnienia czasu P. Hoenen SJ. Definicję czasu podaną przez Arystotelesa uważa za tzw. definicję operacyjną, ponieważ Stagiryta analizował czynność duszy liczącej i tę czynność wprowadził do określenia czasu. Nie jest to jednak definicja klasyczna przez najbliższy rodzaj i różnicę gatunkową. Dusza, nazywając punkty drogi w ruchu jedne wcześniejszymi a drugie poźniejszymi i licząc części według porządku ich następstwa, tworzy pojęcie czasu jako liczby tych części. Samo liczenie przez duszę jest potrzebné tylko do utworzenia pojęcia czasu, a nie dla ukonstytuowania go w sobie.

Hoenen uważa za zbyteczne rozróżnianie czasu na wewnętrzny i zewnętrzny. Na pytanie bowiem, ,kiedy żył Arystoteles" nic nie daje odpowiedź, że , ̇̇ył w czasie swego życia". Czas orzeka coś zewnętrznego dla zdarzenia, o którym mówimy, że miało miejsce w takim czy innym czasie. Czas we właściwym tego słowa znaczeniu jest trwaniem następczym innego ruchu, z którego częścią trwanie rozważanego ruchu jest jednoczesne. Czas we właściwym tego słowa znaczeniu posiada strukturę topologiczną, np. mówimy: „Arystoteles żył w starożytności”, oraz strukturę

58 Dz. cyt., 143-159. 
metryczną, dzięki której wyrażamy czas przy pomicy liczby kardynalnej. Czas tak rozważany spełnia dwie funkcje: chronologiczną i chronometryczną. Rozważany w pierwszej funkcji służy do określenia pozycji jakiegoś zdarzenia $\mathrm{w}$ stosunku do innych zdarzeń stanowiących historię ludzi i świata. Rozważany w funkcji drugiej służy do mierzenia trwania jakiegoś zdarzenia, niezależnie od jego pozycji w historii zdarzeń.

Strukturę topologiczną czasu określa się wystarczająco przez liczbę jakiegokolwiek ruchu. Natomiast liczbę metryczną określa się przy pomocy liczby wziętej z podziału ruchu jednostajnego, praktycznie $z$ ruchu ciał niebieskich. Przedziałom ruchów, które są jednoczesne, przýpisujemy tę samą liczbę, jednoczesnymi zaś są te części ruchu, które zaczynają się od tej samej liczby. Jeżeli ponadto są ograniczone tą samą liczbą, to są także równe $\mathrm{w}$ trwaniu. W ten sposób otrzymujemy według Hoenena jedną liczbę wszystkich ruchów i ta liczba jest czasem. W ten sposób też znajdujemy rzeczywistość, która spełnia funkcję czasu.

Z kolei przechodzi Hoenen do zagadnienia realności czasu. Rozróżnia czas analogiczny do przestrzeni i czas analogiczny do miejsca. Pierwszy jest czasem absolutnym, imaginacyjnym, wiecznie płynącym, niestworzonym, niezniszczalnym $i$ jest bytem umysłu $\mathrm{z}$ podstawą $\mathrm{w}$ rzeczy. Drugi jest czasem realnym, chociaż przyznanie mu realności napotyka na pewne trudności. Gdyby bowiem był liczbą liczącą, to istniałby w samej duszy a nie w rzeczach. Gdyby był liczbą konkretną, to też można by przypuszczać, że jego realność jest niedoskonała i domaga się uzupełnienia przez duszę, aby z liczby liczącej mógł stać się liczbę zliczoną, jak tego zdaje się domagać św. Tomasz.w Komentarzu Sentencyj. Hoenen sądzi, że można jednak przezwyciężyć te trudności i zastrzeżenia, gdyż ruch dostarcza aktualnie liczby i ta liczba wystarcza, by przyznać realność czasowi, w którym odbywają się różne ruchy.

Różne zdarzenia zachodzą jednocześnie lub niejednocześnie i to niezależnie od liczącej duszy. Od strony rzeczy istnieje w poszczególnych ruchach kontakt jednoczesności i w ten sposób jest zachowana obiektywna topologiczna struktura czasu. W samych rzeczach istnieje także równość trwania części ruchów, które przebiegają jednocześnie i w ten sposób zostaje zachowana obiektywna metryczna struktura czasu, również niezależnie od liczącej duszy. Istnieje ponadto obiektywny podział ruchu, którego iiczba jest czasem, jak to widać na przykładzie gwiazdy, która przechodząc przez określony punkt, dzieli ruch dzienny nieba.

Ten czas, który jest obiektywny i niezależny od duszy, otrzymuje uzupełnienie przez czynność duszy tylko wtedy, gdy chcemy uczynić go miarą zdatną do bezpośredniego jej zastosowania do mierzenia trwania ruchów, przez podział jej na odpowiednie jednostki. Tę ostatnią doskonałość czasu można nazwać jego elementem formalnym, natomiast wszyst- 
kie inne elementem materialnym. Jest jednak oczywistym, pisze Hoenen, że ta ostatnia cecha czasu, zależna jedynie od duszy, raczej wchodzi w zakres praktycznego zastosowania pojęcia czasu, aniżeli do jego natury, która jest prawdziwie i wprost obiektywna ${ }^{59}$.

Nauka Hoenena o czasie jest dość zawikłana i niejasna. Niejasność ta pochodzi z próby pogodzenia suarezjańskiego punktu widzenia, uznającego obiektywną realność czasu niezależnie od umysłu ludzkiego, z dopuszczeniem czynności duszy jako elementu formalnego, zgodnie z ujęciem św. Tomasza. Jest to jednak złożenie czysto zewnętrzne, nie wnoszące niczego nowego do obiektywnej realności czasu, niezależnej od umysłu ludzkiego. Próby takiego zewnętrznego składania dwóch odmiennych doktryn o czasie zdarzają się dość często u neoscholastyków. Ponad́lo wyróżnienie struktury topologicznej i metrycznej, a w tej ostatniej funkcji chronologicznej i chronometrycznej, nie przyczynia się do jasnego przedstawienia zagadnienia realności czasu.

K. Nink wystąpił z krytyką arystotelesowskiej koncepcji czasu. Sądzi bowiem, że definicja czasu jako liczby czy miary ruchu (kosmicznego czy duchowego), podana przez Stagirytę, nie zawiera pierwotnego logicznie znaczenia czasu, lecz tylko relacje następczego trwania do przypadłościowych przestrzennych procesów. Ruch trwa również w czasie i dlatego zakłada jego uprzednie pojęcie w formalno-następczym trwaniu. Nink chce dotrzeć do ujęcia pierwotnego znaczenia czasu. By do tego dojść, analizuje najpierw pojęcie czasowości. Za wewnętrzną czasowość rzeczy uważa formalnie sukcesywne trwanie jej istnienia. Tego trwania nie należy pojmować jako sumy chwilowych rzeczywistości czy powtórzenia procesów, bez łączności z trwającym i skierowanym celowo na przyszłość podmiotem. Trwa jednostkowa rzecz, a w niej i wraz z nią trwają jej substancjalne zasady, które konstytuują jej istotę. Czasowość nie jest samym podmiotem, ani jego istotą, ani istotą bytu przygodnego, lecz jest pewną doskonałością, logicznie i w sposób konieczny ugruntowaną w istnieniu ciał. Doskonałość ta odpowiada ich istocie, indywidualności $\mathrm{i}$ istnieniu.

Czasowość, choć nie stanowi istoty bytu przygodnego, to jednak jest dana wraz z jego istotą $w$ ten sposób, że doskonałość trwania, która idzie z konieczności za istnieniem, nie może być dana naraz i jako niepodzielona, lecz jest dana jako realizująca się sukcesywnie. Żaden byt przygodny nie jest zupełnie czasowy, ponieważ każdy posiada metafizycznie konieczne, przedczasowe, niezmienne, wewnętrznie konstytuujące go zasady i niezmienne stosunki rzeczowe. Czasowość jest więc skutkiem i doskonałością istnienia materialnej rzeczy. Czasowość według Ninka obej-

59 Cosmologia, ed. quinta et recognita, Romae 1956; 251-271. 
muje jednakże nie tylko trwanie przypadłości, lecz także trwanie następcze substancji i dlatego nazywa czasowość doskonałością substancjalną. Wobec tego do istoty czasu należy sukcesywne trwanie zarówno przypadłości, jak i substancji.

Nink nazywa trwanie statyczną doskonałością bytu. Rzecz trwając $\mathrm{w}$ istnieniu, jest w czasie o tyle, o ile się urzeczywistnia. Czynność i ruch są ze swej strony również czasowe. Upływ czasu należy rozumieć jako trwanie w sposób następczy, a nie jako płynięcie we właściwym tego słowa znaczeniu, ponieważ czas przysługuje także tym rzeczom, które się nie poruszają. Samo poruszać się, czy być poruszanym, zmieniać się, czy być zmienianym, mierzyć, czy być mierzonym, nie stanowi istoty czasu. Każdy byt materialny posiada swój własny czas ugruntowany na istnieniu. Ciała znajdują się w tym samym czasie jedynie ze względu na wewnętrzną miarę, jaką jest wieczność ${ }^{60}$.

W stosunku do innych neoscholastyków Nink posuwa się dość daleko naprzód, gdy podkreśla czasowe trwanie substancji materialnej i nazywa czas doskonałością substancjalną. Widzi trudności scholastycznej koncepcji czasu, która zdaje się nie stosować do bytu w spoczynku. Podejmuje analogię czasu do wieczności, lecz nie wyprowadza z tego porównania wszystkich wniosków. Nie wiąże jeszcze czasu z istotą rzeczy i dalej podtrzymuje tradycyjne twierdzenie o niezmienności, konieczności i wieczności trwania samej istoty i zasad substancjalnych.

Najbardziej radykalne stanowisko wobec nauki Arystotelesa i św. Tomasza o czasie zajęli $\mathrm{C}$. Th. Isenkrahe i F. Żigon. Isenkrahe krytykuje wprost definicję czasu podaną przez Arystotelesa, jako definicję idem per idem. Jego zdaniem Arystoteles nie tylko nie rozwiązał problemu czasu, lecz ponadto skierował to zagadnienie na fałszywe drogi, gdyż połączył czas z ruchem, chociaż te dwie rzeczywistości nie mają niczego wspólnego ze sobą. Potoczne ujęcie czasu jako płynącego ponad ruchem i spoczynkiem rzeczy, uważa Isenkrahe za słuszne i nie widzi powodu, dla którego miano by je odrzucić. Sądzi, że to właśnie zrozumiał Suarez i dlatego poprawił naukę Arystotelesa o czasie.

Podstawą czasu jest według Isenkrahego nie ruch, lecz przygodny charakter rzeczy, na co wskazuje fakt, że czas biegnie, choćby nie istniał żađen ruch. Również ujęcie następstwa części jednych po drugich nie jest potrzebne do tego, by czas płynąl, z czego znów wynika, że czas nie jest niczym z ruchu. Zaskakujący jest wniosek, jaki z tych myśli wysuwa Isenkrahe. Pisze bowiem, że skoro racja czasu nie leży w zmianie czy ruchu, lecz jedynie w przygodnym charakterze rzeczy, to w konsekwencji musimy przyjąć wniosek, że pojęcie dowieczności (aevum) jest zbędne.

60 Ontologie, Freiburg i. B. 1952, 149-152. 
Isenkrahe odrzuca dalej rozróżnienie czasu na wewnętrzny i zewnętrzny. W celu uzasadnienia tego twierdzenia podaje przykład miary ,,bezpośredniej” i „pośredniej” ciężaru. Położenie wskazówki wagi daje tylko pośrednią miarę wewnętrznego ciężaru przedmiotu, gdyż samego „wewnętrznego" ciężaru nie można mierzyć bezpośrednio. Podobnie, pisze Isenkrahe, ma się rzecz ze scholastycznym pojęciem czasu wewnętrznego i zewnętrznego. Czas zewnętrzny posiada o tyle sens, o ile go posiada „ciężar zewnętrzny” wykazany położeniem wskazówki wagi, w przeciwstawieniu do „ciężaru wewnętrznego" przedmiotu ${ }^{61}$.

Żigon idzie dalej w kierunku myślowym Isenkrahego. Głównym powodem, pisze Żigon, dla którego neoscholastycy nie doszli do pełnej prawdy w nauce o czasie, była zależność ich poglądów od nauki Arystotelesa. Złączył on bowiem czas z ruchem, co jego uczniowie powtarzali za nim jak echo. Jako konsekwencję tej nauki wymyślono dowieczność (aevum) dla duchów. Tymczasem z samej istoty aniołów nie wynika, że muszą trwać $\mathrm{w}$ chwili następnej. Wprawdzie w rzeczywistości tak się dzieje, jednak tylko dlatego, że Bóg podtrzymuje ich w bycie. Ich trwanie jest więc kontynuowane od zewnątrz, wskutek czego odkrywamy w ich trwaniu następstwo części wcześniejszych i późniejszych, podobnie jak w trwaniu czasowym, a to czyni zbędnym pojęcie aevum.

Za Isenkrahem Żigon uważa, że definicja czasu podana przez Arystotelesa jest za ciasna, gdyż obejmuje tylko jeden rodzaj czasu. Widzimy jednak jej wpływ w definicji Żigona, gdy określa czas ogólnie jako miarę istnienia przygodnego w stosunku do następstwa ,,pierwej” i „,później”. Myślenie ludzkie odkrywa $\mathrm{w}$ istnieniu bytu przygodnego aktualne następstwo, a tym samym odkrywa czas. Byt zdolny do ruchu trwa w czasie zarówno w stanie spoczynku jak i ruchu. Podobnie byt zdolny do zmiany trwa w czasie zarówno w stanie zmiany jak i przy braku zmiany. Sama zmiana odbywa się w niepodzielnym momencie, który jako taki nie posiada trwania czasowego, lecz stanowi granicę czasu ${ }^{62}$.

Isenkrahe i Żigon wyzwalają się w największym stopniu spod wpływu arystotelesowskiej koncepcji czasu i wprowadzają daleko idącą w konsekwencji myśl oparcia czasowości o samą przygodność rzeczy. W ten sposób odchodzą bowiem od tradycyjnego kanonu rozważania czasu jako pochodnego $\mathrm{w}$ stosunku do ruchu i zmiany. Czasowość czynią czymś wcześniejszym, gdyż opierają ją o przygodność bytu, gdy sam ruch odbywa się w czasie.

61 Der Begriff der Zeit, w: „Philosophisches Jahrbuch”, Fulda, XV (1902) 23-35.

62 Das Aevum, w: „Philosophisches Jahrbuch”, Fulda, 21 (1908) 483-495. 


\section{LINIE ROZWOJOWE POGLĄDÓW NEOSCHOLASTYCZNYCH NA REALNOSĆ CZASU.}

Analizując wszystkie poglądy na czas w scholastyce i neoscholastyce, można wydzielać poszczególne nurty, lecz można też śledzić rozwój myśli niezależnie od wymienionych trzech kierunków. Przy omawianiu zagadnienia czasu $\mathrm{w}$ pierwszy sposób ważną rzeczą jest obranie odpowiedniej podstawy dla klasyfikacji poglądów. W przeprowadzonych powyżej analizach podstawą podziału był problem roli rozumu i rzeczy $\mathrm{w}$ konstytuowaniu czasu. Każdy podział jest swego rodzaju uproszczeniem i stosowaniem miary przeciętnej, na podstawie której zalicza się danego autora do tego czy innego kierunku. Istnieją jednakże i zalety takiego postępowania. Wielu spośród omawianych autorów łączy myśli Arystotelesa i św. Tomasza z myślami Suareza. Zastosowanie jednolitego kryterium podziału pozwala wykazać, które myśli są zasadnicze dla danego filozofa, a które zostały przyjęte i jakbý z zewnątrz dodane do podstawowej koncepcji.

Im szerszych dokonywamy syntez, tym bardziej zacierają się różnice między poglądami poszczególnych autorów. Im bardziej szczegółowo analizujemy ich naukę, tym jaśniej występują myśli odrębne i oryginalne. Tym być może tłumaczy się stanowisko Z. Zawirskiego, który ujął naukę o czasie wszystkich scholastyków i neoscholastyków w zbyt szeroką syntezę i nie zobaczył zasadniczych różnic $\mathrm{w}$ poglądach na czas w filozofii chrześcijańskiej ${ }^{63}$. Tym też można tłumaczyć stanowisko tych neoscholastyków, którzy jak Hellin zaliczają św. Tomasza i Suareza do jednej grupy, choć jest oczywistym, że ich koncepcje czasu różnią się zasadniczo. Równocześnie nie jest wykluczone, że obranie innej podstawy podziału może rzucić nowe światło na omawiane zagadnienie czasu.

Śledząc rozwój poglądów na czas poprzez wszystkie nurty w scholastyce i neoscholastyce, można wyznaczyć granice, między którymi oscyluje myśl scholastyczna. Z jednej strony stanowi ją myśl, że czas jest dziełem inteligencji czy refleksji ludzkiej i istnieje formalnie w umyśle ludzkim, z drugiej przyznanie czasowi własnej, pełnej realności, niezależnej od umysłu ludzkiego. Poglądy oscylują więc między pojęciem czasu jako formalnie konstytuowanego przez rozum, a pojęciem czasu jako charakterystyki bytu przygodnego. Jest to równocześnie zakres przedziału, "w którym przesuwa się realność czasu z pojęcia bytu rozumowego $\mathrm{z}$ podstawą $\mathrm{w}$ rzeczy $\mathrm{w}$ kierunku wiązania go $\mathrm{z}$ ruchem, zmianą, trwaniem $\mathrm{i}$ istnieniem rzeczy.

Charakterystyczną cechą dla wszystkich nurtów jest to, że zarówno scholastycy jak i neoscholastycy stoją pod przemożnym wpływem tra-

63 Dz. cyt., 42. 
dycyjnej Arystotelesowej koncepcji czasu. Wpływ ten uwidacznia się w rozważaniach roli rozumu i rzeczy, duszy liczącej i części zliczonych w konstytuowaniu czasu. Stąd też prawie wszyscy autorzy analizują arystotelesowską definicję czasu. Jest to po prostu sposób rozważania tego zagadnienia, który dominuje w myśli scholastycznej i neoscholastycznej. Ujmowanie czasu jako porządku następstwa części, jako dzieła inteligencji ludzkiej, to typowy przykład przewagi duszy liczącej i jej roli w konstytuowaniu czasu. Ujmowanie czasu jako realnego następstwa części ruchu czy trwania rzeczy jest typowym dla tych autorów, którzy uszczuplali możliwie najbardziej rolę rozumu i czynili czas niezależnym od umysłu ludzkiego. Według J. J. Baumanna najdalej w tym kierunku poszedł Suarez, który przesunął czas w same rzeczy tak daleko, jak to tylko było możliwe. Dusza odczytuje tylko czas z rzeczy, ale go nie konstytuuje ${ }^{64}$. Tak pisał Baumann przeszło sto lat temu. Dziś wiemy, że próby te poszły dalej, jak to wynika $\mathrm{z}$ analizy poglądów Renoirte'a, Hoenena, Ninka, Isenkrahego i Żigona. Całkowite zerwanie ze stawianiem pytania o roli rozumu i rzeczy w konstytuowaniu czasu, a tym samym zerwanie z tradycją arystotelesowsko-tomistyczną, stanowi próba pojęcia czasu jako istotowego skladnika struktury bytu materialnego ${ }^{65}$.

Interesujące jest to, że zarówno scholastycy jak i neoscholastycy nie zastanawiają się prawie zupełnie nad zagadnieniem, co to znaczy być czy istnieć „w” czasie. Jeden tylko Büchel porusza to zagadnienie, lecz tylko jakby mimochodem. Wydaje się, że przyczyną tego był sposób stawiania zagadnienia czasu. Mianowicie pytano, gdzie istnieje czas, „w” czym istnieje czas, a nie jak byty materialne istnieją „w" czasie. Podobnie patrzyli na problem ci autorzy, którzy za św. Augustynem prowadzili psychologiczne rozważania nad podziałem czasu na przeszły, przyszły i teraźniejszy, gdyż czasy te istnieją tylko „w” umyśle.

Dla 'prawdziwości obrazu trzeba jednakże podkreślić, że istniały w scholastyce świadome, czy podświadome tendencje, które wychodziły poza Arystotelesową koncepcję czasu. Przykładem tego są rozważania nad stosunkiem czasu do wieczności. Zapoczątkował je św. Tomasz, a podjęli je niektórzy neoscholastycy, jednakże nie przeprowadzili analizy do końca i nie wyciągnęli wszystkich wniosków. A przecież myśl ta nasuwa pewne analogie. I tak np. Mouroux rozważając stosunek czasu do wieczności pisze, że wieczność jest samym bytem Boga ${ }^{66}$. Przez analogię można było powiedzieć, że podobnie czas jest samym bytem substancji materialnej. Właśnie ta intuicja leżała u podstaw teorii czasu jako

64 Die Lehren von Raum, Zeit und Mathematik in der neueren Philosophie, Bd I, Berlin 1868, 47.

65 Zob. Teorie czasu scholastyczne a einsteinowska, $702 \mathrm{nn}$.

66 Dz. cyt., 45. 
istotowego składnika struktury rzeczy. Gdyby czas nie należał do samej istoty rzeczy, to byłby dla niej czymś zupełnie zewnętrznym i przypadkowym. Musielibyśmy szukać zewnętrznej przyczyny czasowego rozwoju świata, ze swej natury statycznego i niezmiennego.

Scholastycy i neoscholastycy, opierając się świadomie czy podświadomie na fiksyźmie, nie mogli dostrzec tej możliwości. Ich rozważania poszły w innym kierunku. Nowością w stosunku do Arystotelesa, którą wprowadził św. Tomasz do zagadnienia czasu, było pojęcie aevum, jako pośrednie między wiecznością i czasem. Skutkiem tego było wprowadzenie radykalnej różnicy między stałym trwaniem substancji, a sukcesywnym trwaniem czasowym ${ }^{67}$. Harmonizowało to $\mathrm{z}$ fiksystycznym ujęciem substancji, jako wiecznej i niezmiennej. W takiej sytuacji czas musi pozostać jedną z kategoryj przypadłości i to kategorii tak specyficznej, że do swej konstytucji domaga się czynności rozumu. Substancja sama w sobie nie podlega określeniom czasowym. Czym wobec tego jest czas i jaka jest jego rola $\mathrm{w}$ materialnym świecie? Czy dotyka rzeczy od wewnątrz, czy też ślizga się tylko po ich powierzchni?

Jeżeli przejdziemy z fiksystycznego na ewolucyjne ujęcie substancji materialnej, to zmieni się radykalnie rola i natura czasu. Czas przestaje wtedy być czymś drugorzędnym i wtórnym, a staje się motorem rozwoju, czynnikiem kształtującym i wiodącym rozwój kosmosu. Właśnie ze względu na ten ewolucyjno-egzystencjalny punkt widzenia, który leży u podstaw mojej wizji świata, należy położyć czas w samej substancji materialnej. Czas jest czynnikiem współodpowiedzialnym za rozwój świata aż do granic bytu duchowego. W tej perspektywie nabiera pełnego znaczenia definicja czasu jako istotowego czynnika w strukturze bytów materialnych. Ta nowa perspektywa czasu wiąże się z nowym sposobem patrzenia na rzeczywistość. Obecnie podkreśla się ewolucyjny punkt patrzenia na świat, podkreśla się historyczność procesów i ujmuje się wszystko w kategorii rozwoju.

Pierwszą po mojej próbę rozważania czasu jako samej istoty rzeczy, podaje J. E. Charon, którego pogląd stanowi pewnego rodzaju skrzyżowanie fizykalnej teorii Einsteina $\mathrm{z}$ wizją świata Teilharda de Chardin. Charon sądzi, że tylko język ogólnej teorii względności jest zdolny całościowo rozważać wszechświat w czasie i przestrzeni ${ }^{68}$, i dlatego próbuje dojść do teorii czasu wewnętrznego z analizy tej teorii. Poznając następstwo różnych chwil w nas - pisze - poznajemy czas wewnętrzny bez pomocy naszych zmysiów. Ten czas stanowi u wszystkich bytów żywych element istotny, który pozostaje nawet przy abstrahowaniu od wszelkich danych zmysłowych. Na tej podstawie możemy przejść do rzeczywistości

67 Zawirski, dz. cyt., 40-42.

68 Man in Search of Himself, London 1967, 117. 
zewnętrznej i powiedzieć, że i w niej czas musi być rozważany jako jej istotny element.

Ogólna teoria względności uczy nas, że czas jest związany nierozłącznie z przestrzenią. Einstein podkreślał bardzo mocno, że czasoprzestrzeń jest czymś istotnym dla rzeczywistości zewnętrznej. Dlatego Charon sądzi, że odległość czaso-przestrzenna, która jest wyrażona przez "s" we wzorach fizykalnych, posiada dokładnie to samo znaczenie fizyczne, co czas „wewnętrzny”. W równaniu $\mathrm{s}=\mathrm{cT}$, „T" wyraża czas wewnętrzny. Jedynym pojęciem, które wedlug Charona zdajemy się poznawać intuicyjnie, jest czas wewnętrzny. Razem z fizyką stwierdzamy, że ten czas wewnętrzny ,T" jest elementem koniecznym i wystarczającym do poznania tego, co jest istotne, co formuje naszą rzeczywistość zewnętrzną czyli czaso-przestrzeń ${ }^{69}$.

$\mathrm{Na}$ podstawie szczegółowej teorii względności Einsteina, pisze dalej Charon, mogiłoby się wydawać, że energię należy uważać za ostateczną „substancję” naszej zewnętrznej rzeczywistości. Jednakże materia i energia nie są niczym innym, jak czaso-przestrzenią, która posiada w każdym miejscu szczegółową geometrię. Cały bowiem nasz wszechświat może być opisany w terminach niesprowadzalnej do niczego wcześniejszego substancji czaso-przestrzeni. Tej czaso-przestrzeni nie można pojmować jako pewnej tylko sceny, na której coś się dzieje, lecz także jako samych ,aktorów", gdyż wszystko jest ukonstytuowane przez czaso-przestrzeń.

W związku z pojęciem człowieka ukonstytuowanego jako czaso-przestrzeń nasuwa się pytanie, czym jest $\mathrm{w}$ takim razie psychizm ludzki? By na to odpowiedzieć, Charon wprowadza do swych fizykalizujących poglądów myśli Teilharda de Chardin. Według Teilharda istnieje oddziaływanie jednostki na całość i całości na jednostkę. Ten proces wzajemnej łączności jest realizowany na poziomie elementarnym w sposób dość luźny, natomiast na wyższych stadiach ewolucji w sposób bardziej intensywny. To, co nazywamy myślą - pisze Charon - nie jest niczym innym, jak intensyfikacją i udoskonalaniem tej wzajemnej łączności każdego $\mathrm{z}$ nas ze wszechświatem.

Rola człowieka polega na intensyfikacji związków ze wszechświatem, a to dokonuje się przez poznanie i miłość. Teilhard - pisze Charon nauczył nas kłaść człowieka na osi ewolucji. W tym aspekcie poznanie to konwergencja całej rzeczywistości ku człowiekowi, a miłość to pro-

69 Du Temps de l'Espace et des Hommes, 23: „En resumé, le seul concept dont nous paraissons avoir une connaissance intuitive, c'est-à-dire parfaite, absolue, est ce temps intérieur $\mathrm{T}$; et nous avons la joie de constater, avec la Physique, que ce temps intérieur $\mathrm{T}$ est aussi un élément nécessaire et suffisant pour connaître, l'essentiel de ce qui forme notre réalité extérieure, c'est-à-dire l'espace-temps. En d'autres termes, il faut nous efforcer de décrire toute la réalité extérieure en termes d'espace-temps, et en ces termes seulement, car c'est le seul concept dont nous possédons un sentiment intuitif, c'est-à-dire absolu". 
jekcja człowieka ku całej rzeczywistości zewnętrznej. I na tym polega łączność człowieka ze wszechświatem. Przez poznanie i miłość realizuje się personalizacja człowieka, która przedłuża się przez ewolucję poza śmierć. Tak więc czaso-przestrzeń nie jest bezwładna, lecz jest równocześnie materialna i psychiczna. Bieguny materialny i psychiczny stanowią jakby dwa ogniska wszelkiej rzeczywistości ${ }^{70}$.

Teoria Charona jest niewątpliwie ciekawą i oryginalną próbą zastosowania, względnie wyciągnięcia filozoficznych wniosków, dotyczących natury czasu, z ogólnej i szczegółowej teorii względności Einsteina. Wydaje się jednak, że próba Charona nie oddaje filozoficznej struktury materii, ponieważ wziął on przesłanki bezpośrednio z fizykalnej teorii budowy materii. Sama fizykalna teoria Einsteina nie daje podstaw do takich filozoficznych wniosków, dotyczących zagadnienia czasu ${ }^{71}$. By dojść do tych wniosków, musiał Charon przyjąć inne przesłanki dotyczące struktury materii, a wziął je z teilhardowskiej wizji świata. Ale też dlatego widać tu wyraźne zewnętrzne złożenie matematyczno-fizykalnej teorii Einsteina z ewolucyjną myślą Teilharda.

Przez to złożenie i przez wprowadzenie za Teilhardem dwóch biegunów: materialnego i psychicznego, chciał Charon przekroczyć jakościową jednorodność czaso-przestrzeni, czyli w jego pojęciu całej rzeczywistości materialnej. Wychodząc bowiem z samej czaso-przestrzeni, bez dodatkowych założeń, nie można w konsekwencji dojść do innego wniosku jak tylko do takiego, że psychizm ludzki to tylko bardziej skomplikowane stosunki czaso-przestrzenne. Wprowadzenie bieguna psychicznego jest wyraźnym przejściem na teren innej koncepcji substancji materialnej, koncepcji podanej przez Teilharda de Chardin.

Nie wchodząc bliżej w dalszą analizę teorii Charona trzeba podkreślić, że wysuwa on koncepcję czasu jako istotnego, konstytutywnego składnika substancji materialnej i w ten sposób zbliża się do koncepcji czasu jako istotowego składnika struktury bytu materialnego. Czas stanowi w teorii Charona samą ,substancję" rzeczywistości, czyli w terminach teorii względności płaszczyznę i krzywiznę. Jest to bardzo ramowe ujęcie substancji materialnej, niemniej jednak jest to nowa próba wyjścia poza tradycyjną arystotelesowsko-tomistyczną koncepcję substancji i czasu.

\section{TRUDNOŚCI ZWIAZZANE ZE SCHOLASTYCZNYMI TEORIAMI CZASU.}

Analizując scholastyczne i neoscholastyczne koncepcje czasu, można napotkać pewne trudności, które wskazują na inne aspekty zagadnienia czasu i sugerują inne ujęcia. Pierwsza z tych trudności dotyczy złożenia

70 Tamże, $19-30$.

71 Zob. Teorie czasu scholastyczne a einsteinowska, 761-773. 
dwóch trwań w substancji materialnej. Mianowicie św. Tomasz i tomiści przyjmują trwanie stałe i niezmienne substancji (istoty) bytów materialnych $\mathrm{w}$ aevum, oraz trwanie jej istnienia w czasie. Nie wytłumaczono i nawet nie próbowano wytłumaczyć, dlaczego w tym samym bycie materialnym należy założyć dwa rodzaje trwania, oraz jak pogodzić w jednej rzeczy dwojakie realne istnienie, substancji w aevum, a przypadłości i istnienia w czasie. Trudność tę zauważyli Isenkrahe i Żigon i dlatego odrzucili całkowicie aevum. Wyrażenie, że substancje materialne są poza czasem, zdaje się implikować jakąś wewnętrzną niezgodność tych pojęć. To, co materialne, wydaje się być ze swej natury czasowe. Trudność tę usiłowałem rozwiązać przez rozróżnienie substancji konkretnej i abstrakcyjnej 72. Substancja konkretna jest ze swej istoty czasowa, trwa i rozwija się w czasie. Czas jest istotowym składnikiem konkretnej substancjji materialnej. Natomiast substancja rozumiana abstrakcyjnie jest „wieczna”, niezmienna, poza czasem i jako taka istnieje w umyśle Bożym i ludzkim.

Druga trudność jest również natury teoretycznej. Jeżeli przyjmiemy arystotelesowską koncepcję czasu, to możemy powiedzieć, że w konsekwencji istnienie też nie odbywa się $\mathrm{w}$ czasie, względnie nie musi $\mathrm{w}$ nim trwać. Zachodzi bowiem pytanie, czy ruch, trwanie, istnienie, mogą być w czasie, skoro są podstawą do utworzenia jego pojęcia, które formalnie istnieje w umyśle. Czas jest więc wtórnie aplikowany do ruchu i trwania. Jeżeli zaś czas utożsamia się z ruchem czy trwaniem, jak to przyjmuje Suarez, to czas jest rzeczywistością zbędną. W jednym i drugim przypadku stosunek czasu do ruchu i trwania nie jest $\mathrm{w}$ pełni wyjaśniony.

Trzecia trudność wiąże się $\mathrm{z}$ pojęciem materii pierwszej. Zgodnie z teorią hylemorfizmu substancja materialna powstaje ze złożenia materii pierwszej i formy substancjalnej, które stanowią zasady substancjalne. Jeżeli istota rzeczy, sama substancja, jest poza czasem, gdyż istnieje $\mathrm{w}$ aevum, to konsekwentnie i zasady substancjalne, a więc i materia pierwsza istnieją $\mathrm{w}$ aevum. Lecz $\mathrm{w}$ takim razie na czym polega różnica między bytem materialnym i niematerialnym? Jak zasady substancjalne, które nie podlegają czasowi i przestrzeni, mogą stanowić substancję materialną? Jak mogą czynić to de facto, a nie tylko per definitionem? Czy w konsekwencji nie mają racji ci, którzy podstawowe cząstki materii uważają za psychoidy? ${ }^{73}$.

Czwarta trudność jest natury logicznej. Scholastycy wyprowadzają i wiążą czas ze zmianą czy ruchem. Zgodnie z tego rodzaju koncepcją czasu można wypowiedzieć równocześnie dwa zdania: „,rzecz jest w ruchu”, oraz ,rzecz jest w czasie”. W pierwszym zdaniu orzeczenie „,w ru-

73 Zob. Teoria hylemorfizmu $w$ ujęciu autorów neoscholastycznych, 37-39. 
chu" przysługuje rzeczy przypadłościowo i może być odjęte od rzeczy bez żadnego wpływu na jej istotę, ponieważ rzecz może być w stanie spoczynku. W drugim zdaniu orzeczenie „w czasie" również przysługuje rzeczy według tomistycznej koncepcji czasu przypadłościowo, czy jednak może być odjęte od rzeczywistości materialnej bez dotknięcia w jakiś sposób samej istoty rzeczy? Jeżeli czas idzie za ruchem i jeżeli ruch może być odjęty od rzeczy, to powinniśmy przyjąć, że i czas może być odjęty od rzeczy bez naruszenia jej istoty. Możemy poprawnie powiedzieć, że „rzecz nie jest w ruchu”, lecz czy możemy równie poprawnie powiedzieć, że „rzecz nie jest w czasie"?

Piąta trudność płynie $z$ arystotelesowsko-tomistycznego pojęcia czasu jako przypadłości kategorialnej. Jeżeli czas jest przypadłością, to gdzie istnieje? Jeżeli istnieje formalnie $w$ umyśle, jak chcą tomiści, to nie istnieje w rzeczach, gdyż ta sama przypadłość nie może istnieć formalnie w umyśle i rzeczach. Ponadto jeżeli czas jest bytem rozumu, to jak wytłumaczyć poczucie zależności naszej i rzeczy od czasu? Jeżeli zaś czas jest przypadłością istniejącą $\mathrm{w}$ rzeczach, to rola rozumu jest zbyteczna w konstytuowaniu czasu. Na gruncie tomistycznej koncepcji czasu pozostaje on dalej czymś tajemniczym, według wyrażenia de Munnyncka jest torturą dla filozofa ${ }^{74}$.

Szósta trudność wiąże się również z tomistyczną koncepcją czasu. Według niej czas jest ukonstytuowany przez rozum i istnieje formalnie w umyśle. Jeżeli tak jest, to czas nie istniał formalnie, zanim pojawił się człowiek na ziemi. Prowadzi to do paradoksu, że czas nie istniał w kosmosie i pojawił się dopiero wraz z umysłem ludzkim. Niczego nie rozwiąże odpowiedź, że istniały zmiany, części wcześniejsze i późniejsze ruchu, gdyż te nie stanowią według tomistycznej koncepcji formalnie czasu. Jẹzeli pomimo tego przyjmiemy, że czas jednak istniał w jakiś sposób, gdyż istniała podstawa czasu, to dochodzimy do nowej trudności, że czas istniał wpierw materialnie zanim zaczął istnieć formalnie, a więc istniał w sposób niezupełny czy niedoskonały.

Neoscholastycy zaczynają zwracać uwagę na te trudności i wyczuwają potrzebę oparcia czasu o istotę bytu materialnego. Te niesprecyzowane bliżej tendencje spotykamy u kilku współczesnych autorów. I tak Renoirte szuka w naturze bytu materialnego przyczyny rozłożenia istnienia w szereg następczy. Mówiąc, że byt jest czasowy, pisze, nie chcemy mówić, że jest $w$ tym momencie i na tym miejscu, ponieważ jest to przypadkowe dla rzeczy. Natomiast mówimy, że charakterystyczne dla bytu materialnego i implikowane $\mathrm{w}$ jego istocie jest to, że musi istnieć

74 Art. cyt., 868. 
W momentach następczych ${ }^{75}$. Na czym ta implikacja polega, tego Renoirte nie wyjaśnia szczegółowiej.

Podobnie Nink, jak to podano wyżej, próbuje szukać rozwiązania zagadnienia natury czasu przez oparcie go o wewnętrzne substancjalne zasady rzeczy. Czasowość rzeczy zakłada według niego przedczasową konstytucję rzeczywistej substancji składającej się z materii pierwszej i formy substancjalnej, oraz odpowiadające im jednolite głęboko celowo uporządkowane stosunki aktu i możności. Ostatecznie czasowość opiera się o wewnętrzne istoty rzeczy, a poznanie czasu łączy się z równoczesnym poznaniem wewnętrznych, przedczasowych, przedempirycznych, substancjalnych zasad rzeczy ${ }^{76}$. Niestety, Nink nie wyjaśnia dokładniej, jak należy rozumieć to oparcie czasu o istotę rzeczy, skoro czas jest według niego doskonałością nie istoty lecz istnienia, a sama substancja wraz z materią pierwszą i formą substancjalną jest poza czasem. Nie tłumaczy więc tego, co najważniejsze, w jaki sposób ponadczasowe może być podstawą dla czasowego.

R. Masi powraca do myśli wysuniętej przez Renoirte'a. Skoro czas, pisze Masi, jest wyłączną własnością rzeczy materialnych, to winien posiadać metafizyczną podstawę $\mathrm{w}$ samej istocie materii. Tę metafizyczną podstawę czasowości, czyli sukcesywnie rozłożonego trwania, widzi w materii pierwszej ${ }^{77}$. Również Masi nie podaje, w jaki sposób materia pierwsza może stanowić metafizyczną podstawę czasowości bytów materialnych, skoro sama nie jest czasową. Jak widać, wymienieni wyżej autorzy nie kładą jeszcze czasu w samej istocie bytu materialnego, przejawiają jednak wyraźne tendencje do stawiania w ten sposób zagadnienia.

\section{CZAS JAKO ISTOTOWY SKEADNIK W STRUKTURZE BYTÓW MATERIALNYCH.}

Po przeanalizowaniu kierunków rozwojowych poglądów na czas u scholastyków i neoscholastyków nasuwa się pytanie, gdzie tkwi trudność, która sprawia, że ich rozwiązania obracają się ciągle w kręgu tych samych koncepcyj. Wydaje się, że tą przyczyną jest przede wszystikim przemożny wpływ arystotelesowskiej i tomaszowej definicji czasu, nawet gdy dany autor jej się przeciwstawia. Wychodząc z tej koncepcji czasu, nie można dojść do nowych rozwiązan, można tylko dotychczasowe rozwijać, rozszerzać i pogłębiać. By rzucić nowe światło na problem czasu, trzeba to zagadnienie postawić inaczej, rezygnując $z$ przyjmowania a priori koncepcji perypatetycznej. Drugą przyczyną, która nie pozwala

75 Dz. cyt., 225.

76 Dz. cyt., $150,153$.

77 Dall'analisi fisica all'analisi metafisica della materia: Ilemorfismo, w: Sapientia Aquinatis, vol. I, Romae 1955, 135-136. 
wyjść z kręgu tej koncepcji, jest szukanie podstawy czasu w ruchu czy zmienności rzeczy. Stąd pogląd na genezę pojęcia czasu obraca się ciągle w granicach rozumu i trwania następczego rzeczy. Wreszcie trzecią przyczyną jest apodyktyczne traktowanie czasu jako jednej z kategorii przypadłości.

Chcąc dojść do nowego ujęcia zagadnienia, spróbujmy odrzucić uprzednie założenia i postawmy zasadnicze pytanie inaczej. Jest już truizmem twierdzenie, że postawienie pytania wyznacza odpowiedź i skierowuje wysiłki poznawcze na $z$ góry przewidziane tory. Zmiana pytania pociąga za sobą zmianę rozwiązania lub przynajmniej wskazuje na nowe aspekty zagadnienia. Scholastycy i neoscholastycy pytają: w jaki sposób dochodzimy do pojęcia czasu, gdzie on istnieje, w rozumie czy w rzeczach i co jest podstawą dla utworzenia jego pojęcia. Opierając się o codzienne doświadczalne stwierdzenie faktu istnienia ruchu czy zmian, brano je za podstawę czasu. W ruchu czy zmianach zachodzi następstwo części jednych po drugich i to ,pierwej” i ,ppóźniej” wzięto za podstawę i warunek istnienia czasu. Wskazuje zresztą na to przyjmowana powszechnie definicja czasu jako liczby (miary) ruchu według „,pierwej” i ,później”. Pojęcie to stało się więc pochodne w stosunku do pojęcia zmienności i ruchu.

Spróbujmy postawić to zagadnienie inaczej. Wychodzimy również z codziennego doświadczenia, że byty materialne są zmienne (stwierdzenie to zyskuje dzisiaj głębszą podstawę i nowe wymiary dzięki teorii ewolucji). Postawmy pytanie: dlaczego byty materialne są zmienne, dlaczego ich trwanie jest rozłożone w szereg następczy? Odpowiedź na te pytania posiada zasadnicze znaczenie dla poglądu, że czas wchodzi w samą istotę bytu materialnego. Brzmi ono: byt materialny istnieje jako zmienny, gdyż taka jest jego wewnętrzna struktura. Inaczej to ujmując, byt materialny jest ze swej istoty czaso-przestrzenny i dzięki temu jego trwanie podlega zmianom. Przy założeniu teorii ewolucji zmiany te będą zarówno istotowe jak i przypadłościowe.

W stosunku do scholastyki i neoscholastyki zachodzi różnica w punkcie wyjścia. Scholastycy wychodzili od pojęcia czasu i szukali uzasadnienia jego realności $\mathrm{w}$ następczych zmianach $\mathrm{w}$ rzeczach. $\mathrm{W}$ nowym poglądzie pytamy, co jest przyczyną zmiennego trwania substancyj materialnych i dochodzimy do wniosku, że taka jest struktura bytu materialnego. Ta struktura jest przyczyną jego rozłożenia w czasie i przestrzeni. Odpowiedź ta jest wprost przeciwna do odpowiedzi scholastyków. Zgodnie $\measuredangle$ nowym punktem wyjścia byt jest czasowy nie dlatego, że jest zmienny, lecz odwrotnie, dlatego jest zmienny, że jest czasowy. Nie czas idzie za zmianami, lecz zmiany idą za czasem.

Nowa koncepcja czasu przeciwstawia się radykalnie poglądowi ogółu 
scholastyków. Stawiając jednak problem czasu w stosunku do nich „na głowie", nie miałem zamiaru dążyć do oryginalności, czy czynienia jakiegoś „,kopernikańskiego przewrotu” w tej dziedzinie. Nie chcę też twierdzić, że jest to jedynie słuszna droga do rozwiązania zagadnienia czasu. Odwracając zagadnienie, chciałem tylko wejrzeć głębiej w strukturę bytu materialnego, szukać przyczyn, dla których nim jest i przebadać ukryte $\mathrm{w}$ tak postawionym zagadnieniu nowe możliwości rozwiązania. Okazuje się zresztą, że nie jest to rozwiązanie tak absurdalne, jak sądzono początkowo, gdyż niektórzy autorzy, jak to podano wyżej, zdają się ostatnio zmierzać w kierunku takiego właśnie rozwiązania problemu czasu. Może wiele zagadnień związanych $\mathrm{z}$ istotą bytu materialnego zyska $\mathrm{w}$ ten sposób nowe naświetlenie i zbliży do siebie rozbieżne dotychczas filozoficzne i fizykalne ujęcia istoty rzeczy.

W nowym ujęciu ani rozum, ani sukcesja zmian nie konstytuuje czasu. Czas nie stanowi czegoś zewnętrznego dla istoty rzeczy, lecz stanowi czynnik konstytuujący samą substancję materialną. Właśnie dzięki niemu rzecz jest materialna ze swej istoty, a więc istnieje jako rozłożona w czasie i przestrzeni. Takie pojęcie czasu, a w konsekwencji i przestrzeni, domaga się zmiany perypatetycznego pojęcia substancji i jej złożenia. W bytach stworzonych można wyróżnić istotę abstrakcyjną i konkretną. Istota abstrakcyjna, czysta, stanowi niezmienną metafizyczną istotę jako produkt posuniętej do końca abstrakcji. Taka istota istnieje tylko w rozumie. Istota konkretna jest realnie istniejącym podmiotem o określonej strukturze istotowej. Struktura czaso-przestrzenna sprawia, że dany byt jest substancją materialną i odróżnia go od substancji duchowej. Z tą strukturą wiąże się cała dynamika i ewolucyjny rozwój materialnego kosmosu ${ }^{78}$. Analiza substancji materialnej dokonana przez scholastyków dotyczy istoty abstrakcyjnej, złożonej z materii pierwszej i formy substancjalnej, które same nie istnieją i dopiero razem tworzą substancję materialną. Same zasady i substancja z nich złożona istnieją ponad czasem, a więc w płaszczyźnie innej, niż konkretna, dotycząca bytu materialnego.

Scholastycy odróżnili stałe trwanie substancji od sukcesywnego trwania ruchu. Tylko następstwo chwil w sukcesywnym trwaniu stanowi podstawę czasu, gdyż sama substancja nie podlega określeniom czasowym. Nowy punkt widzenia łamie tę przegrodę, gdyż konkretna substancja, rozważana ewolucyjno-egzystencjalnie, nie jest abstrakcją, składającą się $\mathrm{z}$ podwójnego trwania. Zgodnie $\mathrm{z}$ ewolucyjnym ujęciem kosmosu sub-

i8 Rozróżnienie istoty abstrakcyjnej i konkretnej tłumaczy być może rozbieżność ujęć racjonalizmu i empiryzmu filozoficznego. Racjonalizm analizuje czyste istoty i dlatego odkrywa niezmienne i wieczne składniki bytu. Natomiast empiryzm bada istotę konkretną i dlatego odkrywa w bycie dynamizm, zmienność i rozwój. Równocześnie empiryzm zbliża się przez to bardziej do nauk szczegółowych, które badają istoty konkretne. 
stancja materialna nie jest tylko stałą podstawą zmian, lecz sama ze swej natury jest także aktorem historii i rozwoju. Scholastyka przesuwa rozwój w sferę przypadłości, gdy nowy punkt widzenia wprowadza go w samą istotę materii. Dla scholastyki ewolucja ślizga się po powierzchni materialnej rzeczywistości, po jej stronie przypadłościowej. Nowe ujęcie wprowadzając czas w samą istotę materii, tłumaczy rozwój zgodnie z naukową teorią ewolucji, jako zmiany istotowe w kierunku coraz to doskonalszych bytów. Tłumaczy sens ewolucji całego kosmosu, którego rozwój dojdzie do kresu, gdy cały wszechświat przekroczy bios, wyzwoli się spod panowania i samowładztwa biosu, który jest panowaniem śmierci. Nie tylko człowiek, lecz także cały kosmos przekroczy granice śmierci, gdy drogą ewolucji przejdzie na dowieczno-immanentną ${ }^{79}$ płaszczyznę bytową. Ewolucja wyniesie bowiem nie tylko człowieka, lecz także cały kosmos ponad granice przestrzeni i czasu ${ }^{80}$.

Ujęcie czasu, a wraz $z$ nim przestrzeni, jako istotowego składnika substancji materialnej pozwala na lepsze zrozumienie i ocenę czynnika duchowego w człowieku. Kosmos dochodzi stopniowo do przekroczenia bariery czasu i przestrzeni najpierw w człowieku. Psychizm ludzki, dzięki któremu człowiek wchodzi w świat duchowy, w stosunku do psychizmu zwierzęcego powstaje przez przekroczenie przy pomocy specjalnej interwencji Bożej bariery czy progu płaszczyzny przestrzenno-czasowej, która wiąże psychizm niższy i przez wejście w płaszczyznę dowieczno-immanentną ${ }^{81}$. Psychizm ludzki przez uwolnienie się z więzów czasu i przestrzeni wyzwolił się z biosu, choć cały człowiek nie wyszedł jeszcze całkowicie $z$ niego. Zajmuje jednak wobec niego stanowisko transcendentne, co pozwala mu na samoświadomość, oraz ujęcie kosmosu i swego stosunku do niego. Powstanie psychizmu ludzkiego to antycypacja tego, co czeka cały kosmos przy końcu świata.

Tak więc dusza ludzka nie jest czymś dodanym, czymś obcym w kosmosie, lecz jest jego najlepszą cząstką, która przekroczyła przestrzeń i czas. Człowiek nie jest bytem złożonym z duszy i ciała, lecz jest osobą w swej istocie cielesno-duchową. Osoba ludzka jest częściowo zanurzona w materialnym kosmosie, a częściowo, dzięki transcendującemu skokowi, jest wyniesiona ponad niego. Człowiek jest istotą na pograniczu dwóch płaszczyzn rzeczywistości. Jedną jakby stopą tkwi w płaszczyźnie czasowo-przestrzennej, a drugą w płaszczyźnie dowieczno-immanentnej, do

79 Zob. wyjaśnienie tych terminów w: Teorie czasu scholastyczne a einsteinow$s k a, 708$.

${ }_{80}$ Podobne myśli wypowiada J. Ratzinger, Wprowadzenie w chrześcijaństwo, Kraków 1970, 251.

${ }^{81}$ Tego rodzaju ujęcie nie powinno budzić gwałtownych sprzeciwów u tomisty. Wystarczy tylko przyjąć $w$ pełni teorię wyprowadzania form $\mathrm{z}$ możności materii przy pomocy specjalnej interwencji Bożej. 
której przesunie się cały po zmartwychwstaniu. Równocześnie dzięki transcendencji ponad materię człowiek widzi punkt wyjścia i drogę, którą przebył rozwijający się kosmos, oraz dostrzega drogę wiodącą go przez doskonalenie siebie i kosmosu do punktu wyjścia, którym jest Stwórca. To jest moja chrześcijańska wizja całego kosmosu, która nabiera życia $\mathrm{w}$ ewolucyjno-egzystencjalnym ujęciu rzeczywistości. Statyczna prawda nabiera cech życia i staje się życiem.

\section{Z U S A M M E N F A S U N G}

\section{SCHOLASTISCHE UND NEOSCHOLASTISCHE AUFFASSUNGEN DES ZEITBEGRIFFES}

Der vorliegende Artikel bildet eine Fortsetzung der Erwägungen über den Zeitbegriff, die in der Arbeit unter dem Titel, „Die scholastischen Theorien über den Begriff der Zeit und die Einsteinsche Zeittheorie" enthalten sind. Im Aufsatz werden die Anschauungen jener Autoren besprochen, die in der erwähnten Arbeit nicht berücksichtigt wurden. Hinzugefügt wurden ausserdem Ergänzungen und Korrekturen, sowie eine umfassende kritische Beurteilung der scholastischen Auffassungen des Zeitbegriffes. Es wurde hierdurch eine vollere und exaktere Umreisung des Problems ermöglicht.

Unter den Autoren der thomistischen Richtung wurden diejenigen ausführlicher besprochen, die mit neuen Ideen die traditionelle thomistische Auffassung des Zeitproblems bereichert haben. Kleine Änderung ist auch in Bezug auf die suarezianische Richtung eingeführt. Es zeigt sich nämlich, ảass schon im Mittelalter der suarezianischen Anschauung ähnliche Fassungen des Zeitbegriffes beim hl. Albertus Magnus, Roger Bacon, sowie im Werk „De rerum principio” aufzufinden sind. In der spanischen Scholastik wurden ähnliche Ideen von Emmanuel de Goës entwickelt. Einige zu dieser Autorengruppe gehörende Neuscholastiker sind mit einer Kritik der aristotelisch-thomistischen Auffassung der Zeit aufgetreten. Sie suchen die metaphysische Grundlage der Zeit im Wesen des materiellen Seins und insbesondere in dem Urstoff (materia prima).

Das gemeinsame und charakteristische Kennzeichen aller scholastischen und neuscholastischen Anschauungen über die Zeit bildet die Übernahme der Betrachtungsweise mit der Aristoteles und der hl. Thomas an das Problem der Zeit herangingen. Die Scholastiker und Neuscholastiker gehen über die Betrachtung der Zeit als einer Kategorie des Akzidenz nicht hinaus, wobei diese nach Ansicht der Thomisten so weit spezifisch ist, dass sie eine aktive Rolle der Vernunft für die Begründung des Zeitbegriffes erfordert. Ein weiteres Kennzeichen, das übrigens eine Folge des ersten darstellt, ist das mangelnde Interesse der Neuscholastiker in Bezug auf die Frage was es bedeutet ,in der Zeit zu sein”. Daher ist es nicht verwunderlich, dass sie nicht im Stande waren über die aristotelische Definition der Zeit hinauszukommen und umsomehr nicht zu einer vollen Anlehnung des 
Zeitbegriffes an das Wesen der Dinge gelangen konnten, obwohl ihrerseits gewisse Schritte in dieser Richtung unternommen worden sind.

Bei der analytischen Betrachtung der scholastischen und neuscholastischen Zeittheorien treten gewisse Schwierigkeiten auf, von denen im Artikel folgende angeführt wurden: 1. das Problem des zweifachen Dauerns im materiellen Sein, nämlich der Substanz im Aevum und des Akzidens in der Zeit; 2. das Fehlen einer Erläuterung der Beziehung des Urstoffes zur Zeit; 3. die aus der logischen Analyse folgender Sätze resultierenden Folgen: „das Ding ist in Bewegung”, sowie: „das Ding ist in der Zeit”; 4. die mit der Kategorie des Akzidens verbundenen Schwierigkeiten; 5. die Beziehung der menschlichen Vernunft zur thomistischen Zeitkonzeption.

Im Weiterem wurde die Konzeption der Zeit als Wesensbestandteil der materiellen Substanz analytisch untersucht. Als Bedingung, um zu einer neuen Auffassung des Zeitbegriffes zu gelangen, muss man von den vorherigen Annahmen Abstand nehmen und den Ausgangspunkt ändern. Die Sicholastiker gingen von der Definition der Zeit als Zahl (Mass) der Bewegung hinsichtlich des „Früher und Später" aus und stellten dann die Frage bezüglich der Rolle der Vernunft und der Dingen in der Begründung des Zeitbegriffes. Wir gehen bei der neuen Fassung von der Feststellung der Tatsache aus, dass die Dinge veränderlich sind und suchen eine Erklärung für diese Tatsache. Auf der Suche nach einer Lösung kommen wir zur Schlussfolgerung, dass die Dinge veränderlich sind, weil eben ihre Wesensstruktur, wegen der sie als veränderlich bestehen müssen, derart gestaltet ist. Anders ausgedrückt, die Dinge sind deshalb veränderlich, weil sie ihrem Wesen nach räumlich-zeitlich sind. Als Folge einer solchen Anschauung des Zeitbegriffes, tritt die Notwendigkeit auf, die traditionelle Auffassung der Substanz zu ändern.

Die Auffassung der Zeit als wesentlichen Bestandteil der materiellen Substanz wirft neues Licht auf das Problem der Evolution des materiellen Seins. Eben die Zeit ist es, die den wesentlichen inneren Faktor der Veränderlichkeit materieller Substanz und ihrer Evolution in Richtung immer vollkommenerer Formen des Seins darstellt. Die neue Auffassung der Zeit weist gleichzeitig auf die Möglichkeit hin die Genese der Menschenseele zu erklären. Das menschliche Psychismus dem der Mensch den Eintritt in die geistige Welt verdankt, entsteht durch das Überschreiten der zeitlich-räumlichen Barriere mit Hilfe der besonderen und unmittelbaren göttlichen Intervention. Indem sich Mensch in seinem geistigen Teil der Zeit- und Raumfesseln entledigt, befreit er sich vom Bios und nimmt ihm gegenüber eine transzendente Stellung cin. 